\title{
Molekuláris genetikai vizsgálatok primer immundefektusokban
}

\author{
Erdős Melinda dr. \\ ${ }^{1}$ Debreceni Egyetem, Általános Orvostudományi Kar, Infektológiai és Gyermekimmunológiai Tanszék, Debrecen \\ ${ }^{2}$ St. Giles Laboratory of Human Genetics of Infectious Diseases, The Rockefeller University, New York, NY, \\ Amerikai Egyesült Államok
}

Mottó:

Ha nem ismered a tüt, nem találsz rá a szénakazalban.

\begin{abstract}
Az új generációs szekvenálási módszerek a molekuláris genetikai diagnosztika legújabb korszakát jelképezik. A szerző a primer immundeficientiákról írt általános bevezetőt követően összefoglalja a molekuláris genetikai vizsgálatok, különösen az új generációs szekvenálás jelentőségét a primer immundeficientiák diagnosztikájában. A közlemény célja továbbá, hogy rövid történeti áttekintésen keresztül megismertesse az új generációs szekvenálás módszertani alapjait. A szerző összehasonlítva elemzi a primer immundeficientia génpanel-szekvenálás, valamint a teljesexom- és a teljesgenom-szekvenálás előnyeit és hátrányait. Összefoglaló táblázatban kerülnek bemutatásra az új generációs szekvenálásnak köszönhetően eddig felismert primer immundeficientia gének és betegségek. A szerző végül részletesen ír arról, hogy primer immundefektusokban a génszintű diagnosztika miért nem nélkülözhető, és bemutatja a Magyarországon korábban elért eredményeket.
\end{abstract}

Orv Hetil. 2018; 159(49): 2095-2112.

Kulcsszavak: primer immundeficientia, új generációs szekvenálás, molekuláris genetika

\section{Molecular genetic studies in primary immunodeficiencies}

\begin{abstract}
Next generation sequencing methods represent the latest era of molecular genetic diagnostics. After a general introduction on primary immunodeficiencies, the author summarizes the importance of molecular genetic studies, especially next generation sequencing in the diagnosis of primary immunodeficiencies. Another purpose of the manuscript is to give a brief summary on the methodological basis of next generation sequencing. The author analyzes the advantages and disadvantages of primary immunodeficiency gene-panel sequencing and whole-exome and wholegenome sequencing. Primary immunodeficiency genes and diseases recognized by next generation sequencing is also summarized. Finally, the author emphasizes the indispensability of gene level diagnostics in primary immunodeficiencies and presents the results achieved in this field in Hungary.
\end{abstract}

Keywords: primary immunodeficiency, next generation sequencing, molecular genetics

Erdős M. [Molecular genetic studies in primary immunodeficiencies]. Orv Hetil. 2018; 159(49): 2095-2112.

(Beérkezett: 2018. június 5.; elfogadva: 2018. július 7.)

\section{Rövidítések}

$\mathrm{AD}=$ autoszomális domináns; $\mathrm{AF}=$ (allele frequency) allél frekvencia; AID = (activation-induced cytidine deaminase $)$ aktiváció-indukált citidin deamináz; APECED = autoimmun polyendocrinopathia, candidiasis, ectodermalis dystrophia; $\mathrm{AR}=$ autoszomális recesszív; CADD $=($ combined annotation dependent depletion) kombinált annotáció-függő depléció (egy nukleotidot érintő változások, inszerciók és deléciók károsító hatásának meghatározására szolgáló módszer, amely több vizs- gálómódszer eredményeit integrálja egy számértékbe); $\mathrm{CD}=$ (coverage depth) lefedettségi mélység; CGD $=$ (chronic granulomatous disease) krónikus granulomás megbetegedés; $\mathrm{CNV}=$ (copy number variation) kópiaszám-variáció; DNS = dezoxiribonukleinsav; FISH = fluoreszcens in situ hibridizáció; GDI = (gene damage index) génkárosodási index; GOF = (gain-offunction) funkciónyerő mutáció; GQ = (genotyping quality) genotipizálási minőség; HTP = (high-throughput) nagy áteresztőképességü; Ig = immunglobulin; IPEX = immundiszre- 
guláció, polyendocrinopathia, enteropathia, X-hez kötött; IUIS $=$ (International Union of Immunological Societies $)$ Immunológiai Társaságok Nemzetközi Szövetsége; LOF = (lossof-function) funkcióvesztő mutáció; MPS = (massively parallel sequencing) masszív parallel szekvenálás; $\mathrm{MRR}=($ minor read ratio) legkisebb olvasási arány; $\mathrm{MSC}=$ (mutation significance cutoff) szignifikáns mutáció küszöbérték (a várható legalacsonyabb, klinikailag/biológiailag még releváns CADD-érték egy adott gén esetében); NGS = (next generation sequencing) új (következő $)$ generációs szekvenálás; $\mathrm{PCR}=($ polymerase chain reaction) polimeráz-láncreakció; PID = (primary immunodeficiency) primer immundeficientia; PIDD $=$ (PID disorder $)$ PID-betegség; RAGl = recombination activating gene $1 ; \mathrm{RC}=$ (read coverage $)$ olvasási lefedettség; SCID $=($ severe combined immundeficiency) súlyos kombinált immundeficientia; SDS = (Shwachman-Diamond syndrome) Shwachman-Diamondszindróma; SMRT $=$ (single molecule real-time) egymolekulás, valós idejü $;$ WAS $=$ Wiskott-Aldrich-szindróma WES $=($ wholeexome sequencing) teljesexom-szekvenálás; WGS = (wholegenome sequencing) teljesgenom-szekvenálás; WHIM = (warts, hypogammaglobulinemia, infections, myelokathexis) szemölcsök, hypogammaglobulinaemia, infekciók, myelocathexis; WHO = (Word Health Organization) Egészségügyi Világszervezet; XLP $=(\mathrm{X}$-linked lymphoproliferative disease $)$ X-kromoszómához kötött lymphoproliferativ betegség

Az Egészségügyi Világszervezet (WHO) égisze alatt múködő IUIS (International Union of Immunological Societies - Immunológiai Társaságok Nemzetközi Szövetsége) legutóbbi, 2017. februárban közzétett klasszifikációja szerint jelenleg 354, genetikailag meghatározott primer immundeficientia (PID-) betegség ismert, amelyek hátterében 344 különböző gén defektusa igazolható $[1,2]$. Az első veleszületett immunhiány-betegség, az X-kromoszómához kötött agammaglobulinaemia felismerése óta (1952, Ogden Bruton amerikai katonaorvos [3]) eltelt évtizedekben tehát a molekuláris genetika nagy léptékú és lenyügöző fejlődésének köszönhetően a primer immundeficientiák jelentős részében a betegség molekuláris genetikai háttere és patomechanizmusa tisztázható volt. Az immundeficientiák molekuláris genetikai kutatása területén tapasztalható hatalmas fejlődés ellenére azonban maradtak kihívások.

\section{A primer immundeficientiákról általában}

A veleszületett immunhiány-betegségek az immunitás monogénesen öröklődő defektusai, amelyekben a következők legalább egyike fenotípusosan is kifejeződik: fertőzés, autoimmunitás, autoinflammatio, allergia és tumor [4-6]. A legtöbb PID változó expresszivitással és gyakran inkomplett penetranciával jellemezhető, így a PID-betegségek klinikailag rendkívül heterogén kórképek. Az immundeficientiák egy része a típusos klinikai tünetek és a jellegzetes kórokozóspektrum alapján egyértelműen felismerhetô, az esetek nagyobb százalékában azonban az immundeficientiák tünettanában átfedések észlelhetők. A diagnózis megállapításához sokszor a részletes anamnézis, a fertőzések etiológiájának, lefolyásának, típusának, lokalizációjának gondos elemzése, az ismételten elvégzett fizikális vizsgálat, a rutin laboratóriumi vizsgálatok és az in vivo és az in vitro immunológiai tesztek elvégzése sem elegendő; az immunhiányos állapotok idejekorán történő felismeréséhez genetikai vizsgálatra is szükség van. Az egyes immunhiány-betegségek ritkák, ugyanakkor összességükben gyakoriak $[7,8]$. Jelenleg az immunitás veleszületett zavarával járó betegségeket az alábbi csoportokra osztjuk:

1) kombinált immundeficientiák,

2) kombinált immundeficientiák szindrómajelekkel,

3) antitestdeficientiák,

4) immundiszregulációs szindrómák,

5) phagocytadefektusok,

6) a természetes immunitás veleszületett zavarai,

7) autoinflammatiós betegségek,

8) komplementdeficientiák.

Azon PID-ek esetében, amelyekben a molekuláris genetikai háttér már 2010 előtt, vagyis az új generációs szekvenálási (next generation sequencing, NGS) érát megelőzően tisztázható volt, döntő többségben (több mint 230 PID-génrő́l van szó) a Sanger-szekvenálásnak volt köszönhetố a diagnózis [9]. Elenyésző számban más molekuláris genetikai vizsgálómódszer segítségével volt azonosítható a betegséget okozó gén. Ennek legismertebb példája talán a FISH- (fluoreszcens in situ hibridizáció) technika alkalmazása Di George-szindróma esetében. Napjainkban, ha az NGS-technika hozzáférhető, a PID első diagnosztikus lépéseként ennek alkalmazása javasolt, míg a Sanger-féle szekvenálás már csak a diagnózis megerősítésére szolgál. A Sanger-féle szekvenálás kutatási célokra történő felhasználása mint első megközelítés szintén elavulttá vált. Ez a technika csak azon ritka esetekben marad diagnosztikai módszer, amikor a beteg fenotípusa egy jól meghatározott genotípusra specifikus. Mindezek miatt a közlemény a génszekvenálás történetének és különböző módszertani lehetőségeinek bemutatására fókuszál, és eltekint a génszekvenáláson kívül esetlegesen alkalmazható további molekuláris genetikai vizsgálómódszerek bemutatásától, mivel azoknak a PID-diagnosztikában nem volt számottevő, jelenleg pedig nincs gyakorlati jelentőségük.

A molekuláris genetikai vizsgálómódszerek robbanásszerú fejlődése ellenére még mindig jelentős azon betegek száma, akikben az immunhiányos állapot klinikailag és laboratóriumilag egyértelmú, de a genetikai diagnózis nem ismert. Az NGS-eljárások ezekben az esetekben rendkívül hatékony eszközt jelentenek a betegségi gének azonosításában. Az ezredfordulót követôen és különösen 2010-tól kezdődően az NGS nagymértékben hozzájárult az újonnan leírt, illetve a már ismert PID-fenotípusok genetikai hátterének megismeréséhez (1. ábra). A különböző génszekvenálási technológiákról jó áttekintést ad két közelmúltban megjelent magyar nyelvú összefoglaló is $[10,11]$. 


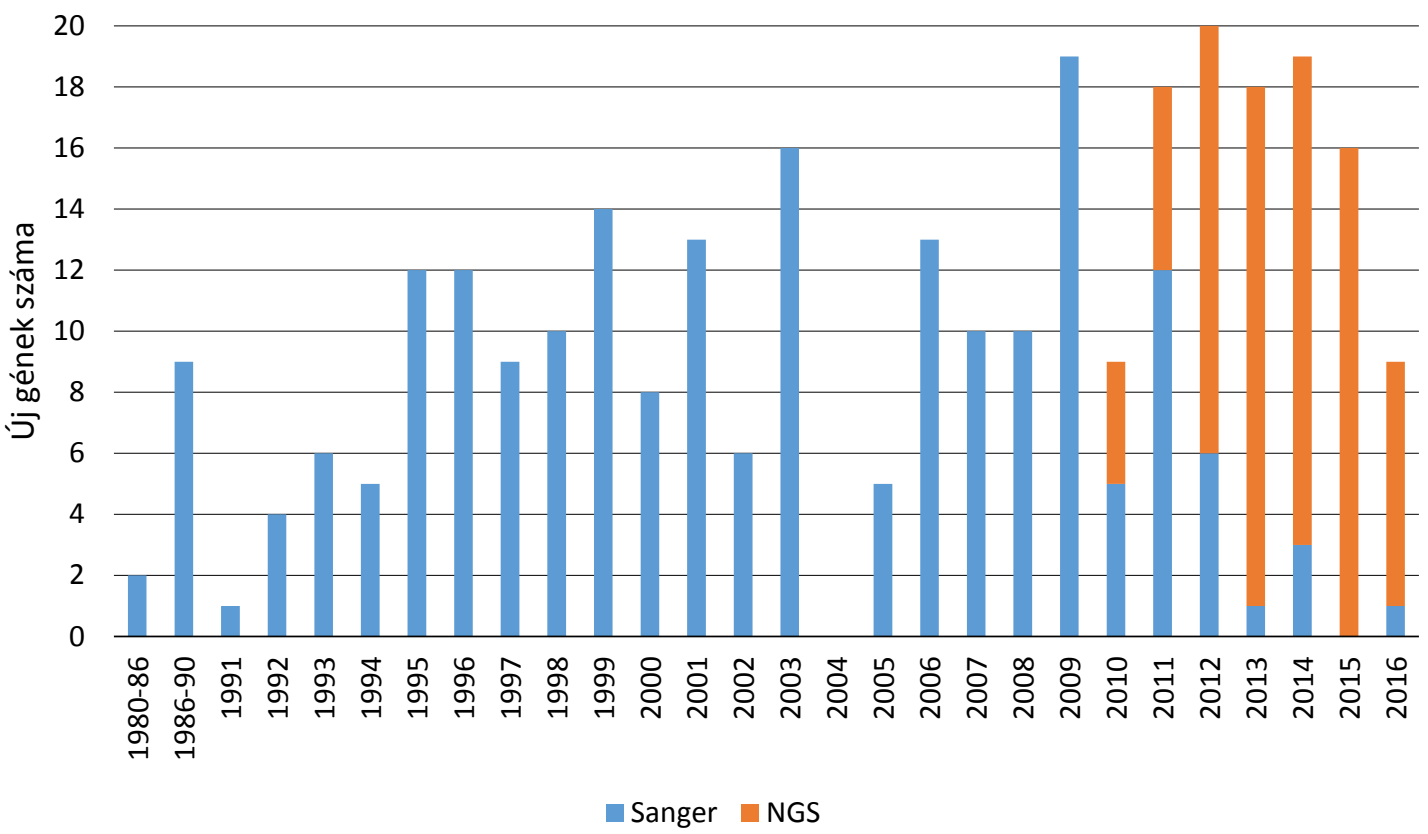

\begin{tabular}{l|l} 
1. ábra & $\begin{array}{l}\text { A Sanger-féle szekvenálás és az NGS segítségével felismert PID-gének számának változása 1980-tól } \\
\text { A diagram jól érzékeltetni az NGS térhódítását a már klasszikusnak mondható Sanger-féle szekvenálással szemben. Látható, hogy 2010-tól a Sanger- } \\
\text { féle szekvenálás fokozatosan átadta helyét az új generációs technikáknak (2004-ben nem volt felismert új gén) } \\
\text { NGS = új generációs szekvenálás; PID = primer immundeficientia }\end{array}$
\end{tabular}

\section{A génszekvenálás fejlődése}

\section{Első generációs szekvenálási módszerek}

A DNS nukleotidsorrendjének meghatározása, vagyis a génszekvenálás időrendben első, meghatározó jelentőségü módszere az úgynevezett Sanger-féle klasszikus láncterminációs módszer volt, amelynek kifejlesztéséért Frederick Sanger 1980-ban megkapta második Nobel-díját (2. ábra) [12]. Az eredeti sangeri DNS-szekvenálási módszer a DNS-szintézis során radioaktívan jelölt didezoxinukleotidokat használt, a különböző hosszúságú DNS-fragmentek elválasztása pedig gélelektroforézissel történt. Autoradiográfiai előhívást követően, körülbelül egy nap múlva manuálisan történt a DNS-szekvencia leolvasása. A módszer legnagyobb hátrányát az jelenti, hogy a leolvasási bázishossz korlátozott, egyszerre csak 500-600 bázis detektálható. Az 1980-as években vezették be a DNS-bázisok eltérô színú fluoreszcens jelölését, a gélelektroforézis után kapott kromatogramból pedig már számítógép segítségével történt a szekvencia meghatározása [13]. Az 1990-es években a bázisspecifikus terminációval lehetővé vált az úgynevezett sokciklusos szekvenálás, a kapilláriselektroforézis-technika kifejlesztésével pedig megoldhatóvá vált igen kis DNS-mennyiségek rövidebb idő alatt történő szétválasztása, így nőtt a leolvasható bázisszám (1000 bázis/80 perc) [14, 15] (2. ábra). A DNS-szekvencia-adatok feldolgozásához szükséges számítógépes szoftverek fejlődésével egyre nagyobb teljesítményü, a szekvencia leolvasását automatikusan végző génszekvenáló készülékek jelentek meg.
A kezdeti egycsatornás automata génszekvenálóktól a technikai fejlődés elvezetett a 32-48 csatornás készülékekig, amelyekkel már akár 800 bázishosszúságú DNSszakaszok szekvenálhatók voltak. Az úgynevezett piroszekvenálási eljárásnak köszönhetően 1996-tól már lehetőség volt valós idejü szekvenálásra is [16]. A biolumineszcencián alapuló piroszekvenálás során a DNS-t építő polimeráz enzim aktivitását valós időben mérik. A nukleotidok DNS-szálba történő beépülésekor pirofoszfát szabadul fel, amelynek mennyisége a kapcsolt enzimreakciókat követő fénykibocsátás révén mérhető. Mivel fényjelenség csak komplementer nukleotid beépülése esetén észlelhető, a rendszerhez pedig egyszerre csak egyféle nukleotidot adnak, meghatározható, hogy éppen milyen nukleotid épült be a DNS-láncba. Az eljárás diagnosztikus korlátja hasonló a Sanger-féle módszeréhez, azaz hosszabb DNS-láncok nem szekvenálhatók. A Sanger-féle láncterminációs módszert és a kezdeti piroszekvenálási eljárást nevezik első generációs szekvenálási módszereknek is.

\section{Ujj generációs szekvenálás, második generációs szekvenálás}

Az időrendben a Sanger-féle láncterminációs módszert és a kezdeti piroszekvenálást követően kifejlesztett eljárásokat nevezzük összefoglalóan NGS-nek. A különböző NGS-eljárásokban közös, hogy egyszerre több százmillió, előzetesen clonalisan amplifikált DNS-szakaszt képesek párhuzamosan (masszívan) szekvenálni, így rövid idő 


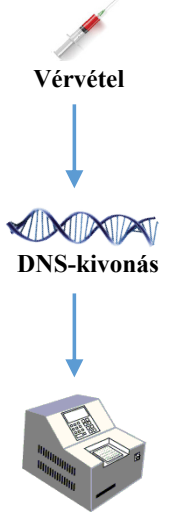

Hagyományos PCR
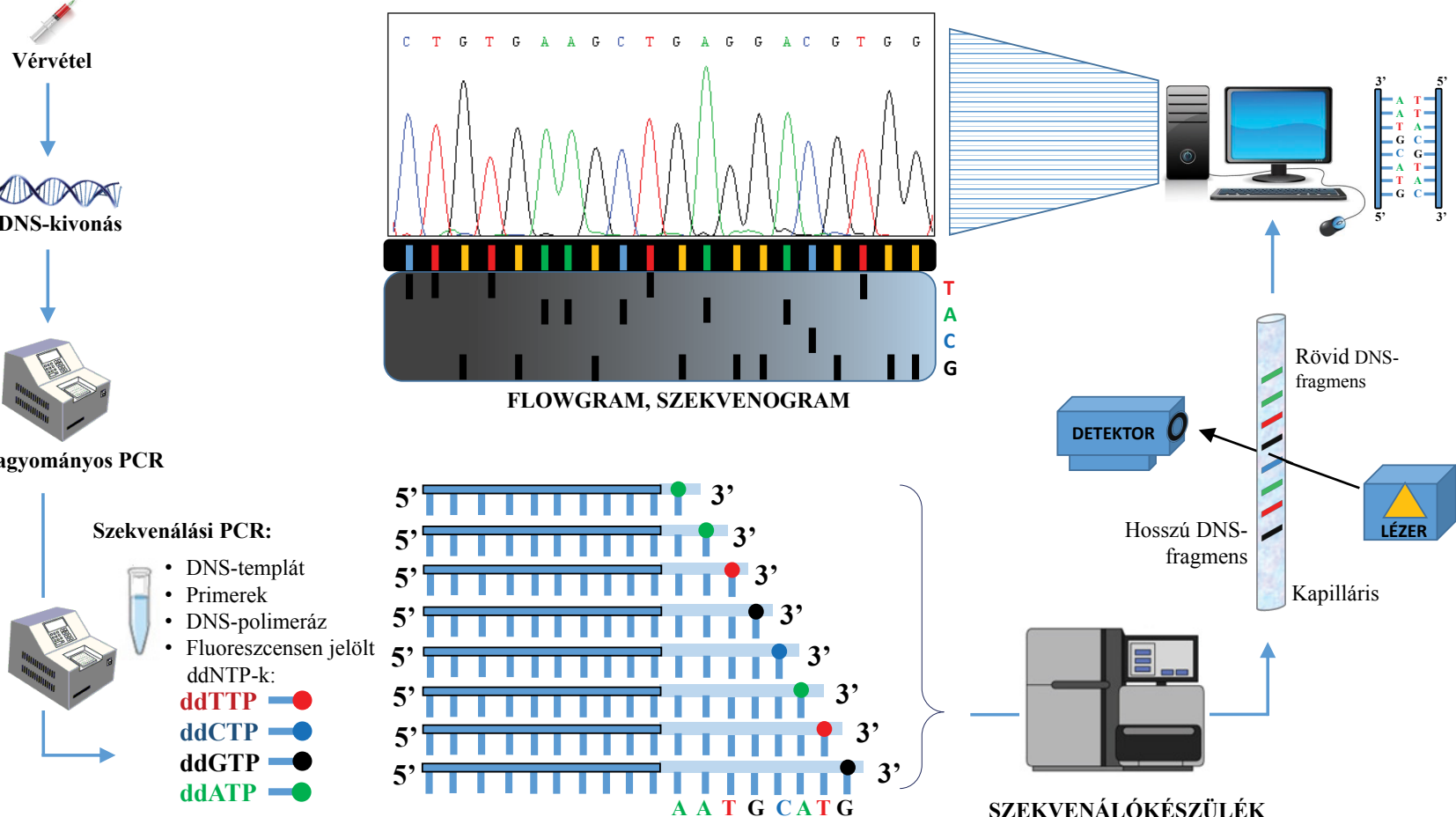

FLOWGRAM, SZEKVENOGRAM

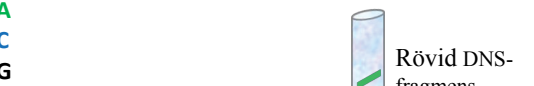

fragmens
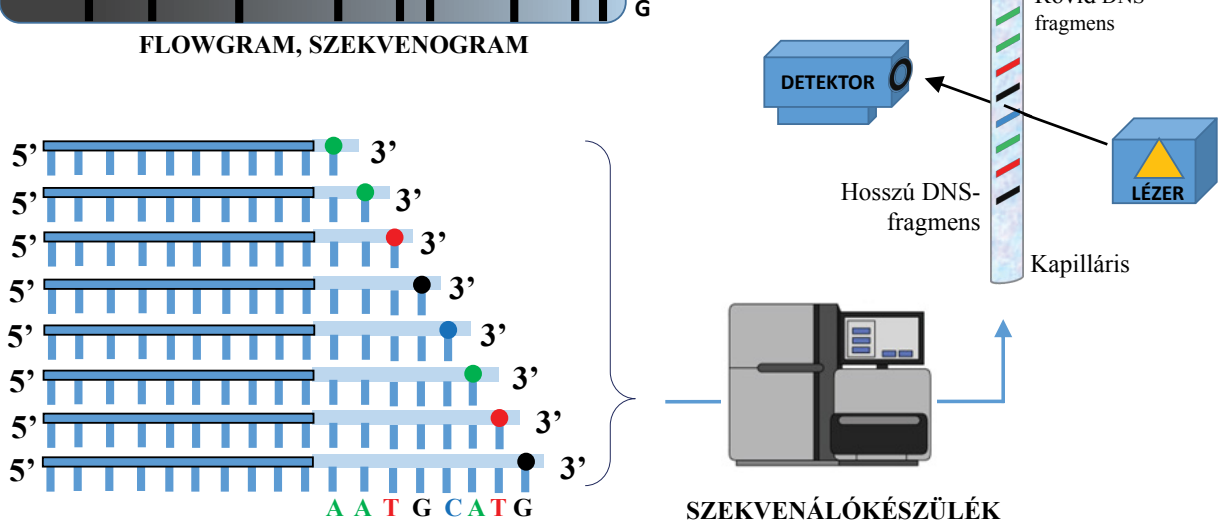

SZEKVENÁLÓKÉSZÜLÉK

2. ábra

\begin{abstract}
Fluoreszcens, automatizált Sanger-szekvenálás
Hagyományos PCR: A DNS kivonását a DNS bizonyos szakaszainak specifikus amplifikációja követi, amelyet polimeráz-láncreakciónak (polymerase chain reaction, PCR) nevezünk. A PCR során hőstabil DNS-polimeráz enzimet használnak, amely csak kétszálú DNS-hez tud hozzákötődni. Az egyszálú DNS egy rövid, körülbelül 10-20 bázisnyi szakaszához ezért 10-20 bázisnyi komplementer oligonukleotidot, úgynevezett primert kötnek, létrehozva egy rövid, kétszálú DNS-szakaszt, amelyhez az enzim már kötődhet. Primerpárok segítségével meghatározható, hogy a teljes genomiális DNS mely szakasza sokszorozódjék meg. Az enzim bizonyos funkciói csak adott, viszonylag szúk hőmérsékleti skálán múködnek, így a hőmérsékleti értékek ciklusos változtatásával úira meg újra megduplázódik a lemásolandó DNS-szakasz, ezáltal többmilliószorosára sokszorosítva azt. Szekvenálási PCR: A reakcióhoz a hagyományos PCR során felamplifikált kétszálú DNS-szakaszra van szükség. A reakcióelegyhez a primerpárnak csak az egyik tagját adják, így ebben a reakcióban csak egyszálú DNS-szakaszt sokszoroznak meg. Ehhez a DNS-polimeráz enzim mellett a normál dNTP-k mellé fluoreszcens festékkel jelölt ddNTP-ket is adnak, amelyek véletlenszerúen beépülve az új szálba leállítják a polimerizációt (lánctermináció). A négy különböző nukleotidot négy eltérő fluoreszcens festékkel jelölik (A-T, C-G), ezáltal olyan, eltérő hosszúságú másolatokat kapunk, amelyek 3' végén jelölt és így azonosítható nukleotid található. Szekvenálás: Az eljárás a DNS-minta bázissorrendjének meghatározására szolgál. Ehhez a szekvenálási reakció során amplifikált és a végén fluoreszcens festékkel megjelölt egyszálú DNS-termékekre van szükség. A kapillárisban a különböző hosszúságú DNS-szakaszok az elektrokinetikus injekció hatására a katódtól az anódig haladnak hosszuk szerint elkülönülve (legelöl a rövidebb, a „sor” végén a leghosszabb DNS-szakaszok haladnak). Amikor a nukleotidok elérik a detektorablakot, a készülék által kibocsátott lézersugár hatására a festék emittált fluoreszcenciája egy kamera segítségével detektálható. A keletkező fluoreszcens képet a számítógépes szoftver a végső szekvenciává dekódolja: minden fluoreszcens sávban (adatpontban) a fluoreszcencia hullámhossza alapján a bázis megnevezhető. A Sanger-szekvenálás kifejezetten lassú és drága az újabb módszerekhez képest, ugyanakkor megbízhatósága jól ismert

dNTP = dezoxinukleotid-trifoszfát; ddNTP = didezoxinukleotid-trifoszfát
\end{abstract}

alatt rendkívül nagy mennyiségú adatot képesek elóállítani, azaz nagy áteresztőképességúek (high-throughput, HTP). Az angol irodalomban az NGS-t nevezik mély szekvenálásnak (deep sequencing), masszív parallel szekvenálásnak (massively parallel sequencing, MPS) és második generációs szekvenálásnak (second generation sequencing) is. A párhuzamos feldolgozásnak köszönhetôen a módszer gyors, az időegység alatt leolvasható bázisok száma egyre nő (több ezer bázis/másodperc), vagyis a végteljesítmény nagyobb. Az NGS a korábbi technológiákhoz képest költséghatékonyabb bázissorrend-meghatározást tesz lehetôvé, a fajlagos költség pedig fokozatosan csökken. Míg egy bázis vizsgálata például 1985-ben még tíz dollárba került, addig az ezredfordulóra ugyanennyi ráfordítással már tízezer bázis volt analizálható. Jelenleg több mint 30 különböző módszerú NGS-platform érhető el. A szekvenált DNSszakasz hossza szerint az NGS-technológiákat rövid és hosszú leolvasásokat lehetôvé tevő platformokra osztják. Az NGS lehet úgynevezett célzott (targeted, t-MPS [rövid leolvasás]), illetve az egész genomot (whole-genome sequencing, WGS) vagy a teljes exomot, az úgynevezett „transzkriptom”-ot (whole-exome sequencing, WES) átfogó (shotgun, s-MPS [hosszú leolvasás]) szekvenálási reakció (3. ábra). A célzott vizsgálatoknál a szekvenálást megelőzi egy előzetes szelektálási lépés, így csak a számunkra érdekesnek gondolt génszakasz(oka)t vizsgáljuk. A célgének számától függően a vizsgálni kívánt génpanel lehet kicsi - ilyen például, ha minden olyan gén, amelyről ismert, hogy immunhiányt okoz, bekerül a vizsgálni kívánt génpanelbe -, de akár az egész exomot felölelően széles is (3. ábra). A hosszú leolvasású NGS- 


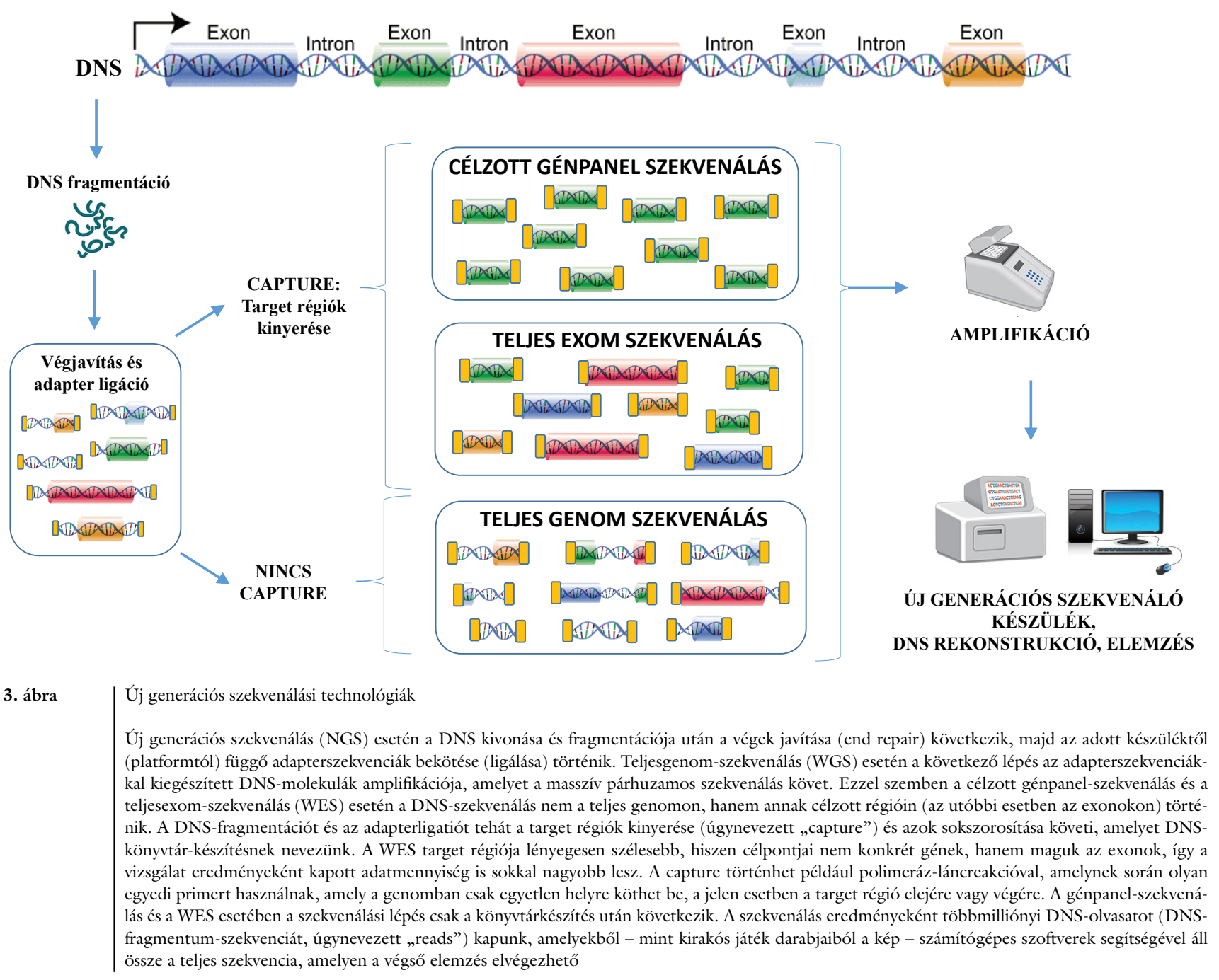

eljárások közé tartozik az úgynevezett félvezető szekvenálási technika (szemikonduktorszekvenálás), amely a piroszekvenálásra emlékeztető elven nyugszik, de nem fény-, hanem protonemissziót mér. A komplementer nukleotid DNS-láncba történő beépülésekor ugyanis hidrogénion szabadul fel, amely $\mathrm{pH}$-mérők segítségével érzékelhető (például Ion Torrent ${ }^{\mathrm{TM}}$; Thermo Fischer Scientific, Waltham, MA, Amerikai Egyesült Államok [USA]). A DNS-fragmentumok clonalis amplifikációja a piroszekvenáláshoz hasonlóan emulziós PCR segítségével történik. A rövid leolvasást lehetővé tévő NGS-platformok egyik típusa a szintézisen alapuló szekvenálás, amelynél DNS-polimerázokat és szolid felülethez rögzített, amplifikált DNS-szakaszokat alkalmaznak. A rendszerhez adott, fluoreszcensen jelölt nukleotid beépülését a kötődés után keletkező fluoreszcens jel segítségével detektálják. A festék lemosása után a nukleotid naturális bázisként múködik tovább, és a ciklus egy újabb nukleotid beépülésével újraindul (például Illumina; San Diego, CA, USA). A rövid leolvasást lehetővé tévő NGS-technológiák másik típusa az úgynevezett ligatión alapuló szekvenálás, amelynél szintén szolid fázisú (híd)amplifikáció segítségével történik a DNS-fragmentumok ampli- fikációja. Az egyik vagy mindkét végén fluoreszcensen jelölt, két ismert bázisból álló próba a komplementer DNS-szakaszhoz kötődik. A fluoreszcens jel alapján a kötések első és második bázisa meghatározható, a reakció pedig ciklikusan megismételhető (például SOLID ${ }^{\mathrm{TM}}$; Thermo Fisher Scientific).

\section{Harmadik generációs szekvenálás}

Az elmúlt évtizedben megjelent az NGS következő generációja. Harmadik generációsnak azon szekvenálási technikák tekinthetők, amelyekre a hosszú DNS-leolvasás mellett jellemző, hogy a DNS előzetes amplifikációja nélkül alkalmasak egyetlen molekula detektálására is. Ezek a készülékek a korábbiak teljesítményét jelentősen felülmúlják, a teljesítmény maximalizálása ugyanakkor a költségek és a munkaidő minimálisra szorítása mellett történik. A leolvasás így nemcsak pontos és nagyon gyors, de olcsó is. Az egymolekulás, valós idejű DNSszekvenálási módszert alkalmazza a Pacific Biosciences (Menlo Park, CA, USA) SMRT (single molecule realtime) szekvenátora. Az SMRT a szintézisen alapuló szek- 
venálás elvét követi. A polimeráz enzim aktivitásának vizsgálatához a négy nukleotidnak megfelelően különböző színekkel fluoreszcensen jelölt és mindkét végükön foszforilált nukleotidokat használnak. A DNS-replikáció során a nukleotid beépülésekor a DNS-polimeráz a fluoreszcens, foszforilált véget lehasítja, a gerjesztő fény hatására kibocsátott fényt pedig egy detektor érzékeli. A nagy mennyiségü fluoreszcensen jelölt nukleotidok zavaró háttérfluoreszcenciáját a korábbi szekvenálási módszerek mosási lépésekkel küszöbölték ki, ami jelentősen lassítja a leolvasást, és anyagveszteséget is okoz, így növeli a költségeket. A SMRT-módszerhez speciális vizualizálókamrákra van szükség, amelyek lehetővé teszik egyetlen DNS-polimeráz enzim múködésének megfigyelését, vagyis egyetlen DNS-molekula valós idejü szintézisének detektálását. A közelmúltban megjelent és a korábbiaktól merőben eltérő Nanopore technológia lényege röviden az, hogy a DNS-szálakat egy félvezető lapra kötött nanoméretü fehérjéból álló póruson vezetik át, és a póruson folyó áram erősségéből következtetnek a DNSszál bázissorrendjére. A molekuláris genetikai fejlődés mindezen vívmányainak köszönhetően 2011-ben már forgalomban voltak olyan szekvenálókészülékek, amelyekkel a humán genomot akár 15 perc alatt meg lehet szekvenálni alig 100 dollár költségen.

\section{Bioinformatikai háttér}

Az NGS alkalmazása elképzelhetetlen bioinformatikai háttér és nagy teljesítményű számítógépek, illetve szoftverek nélkül, hiszen az eredményként megkapott óriási adattömeg (például egy teljesgenom-szekvencia) csak előzetes bioinformatikai feldolgozást követően válik diagnosztikai vagy kutatási célra további elemzésre alkalmassá. A bioinformatikai feldolgozás során a kapott szekvenciát referenciaszekvenciákhoz hasonlítják (ez az úgynevezett alignment), és az így előszűrt szekvencia az, amellyel a részletes kiértékelés megtörténhet. Az összehasonlításhoz a nyilvános adatbázisokban több mint tízezer referencia-genomszekvencia adatai férhetők hozzá, így szûrhetők ki például a nagy gyakoriságú polimorfizmusok, amelyek valószínúleg nem okoznak betegséget. Minden egyes beteg esetében a kódoló génszakaszokat 10-100-szor kell szekvenálni ahhoz, hogy a valódi DNSszekvenciavariánsokat biztosan el tudjuk különíteni a polimeráz enzim vagy a szekvenálókészülék múködéséből fakadó hibáktól, és azonosítani tudjuk a heterozigóta eltéréseket.

\section{Mutációk azonosítása}

A szekvenciavariánsok vizsgálata, ismert vagy addig nem leírt mutációk azonosítása vagy adott esetben új betegségi gének felismerése - már bioinformatikai segítség nélkül - megfelelő molekuláris genetikai ismeretekkel és kellö gyakorlattal is elvégezhető. Ez az egyik legnehezebb feladat, hiszen a bioinformatikai feldolgozás után kézhez kapott, többezernyi szekvenciavariánst tartalmazó adathalmazból kell kiválasztanunk az(oka)t a variáns(oka)t, amely az adott beteg esetében betegségokozó lehet. A közlemény kereteit meghaladja azon filterparaméterek bemutatása, amelyek például a leolvasás minőségi mutatói (például $\mathrm{CD}=$ coverage depth, $\mathrm{GQ}=$ genotyping quality, $\mathrm{MRR}=$ minor read ratio, $\mathrm{RC}=\mathrm{read}$ coverage) alapján vagy az adott gén (például GDI = gene damage index, MSC = mutation significance cutoff), illetve az adott szekvenciavariáns (például $\mathrm{AF}=$ allele frequency, $\mathrm{CADD}=$ combined annotation dependent depletion) tulajdonságai alapján próbálnak következtetni a genetikai eltérés súlyosságára, vagyis betegségokozó voltára.

\section{Az immunológiai hipotézis}

A keresés leszúkítésében a számítógépes szűrőmódszerek (úgynevezett filterezés) mellett az immunológiai hipotézisnek legalább ilyen nagy jelentősége van. A jó immunológiai hipotézis három pilléren nyugszik: az öröklés módjának, a klinikai penetranciának (annak valószínűsége, hogy egy adott genotípust hordozó egyén egy adott fenotípust mutat) és az adott betegség genetikai heterogenitásának (különböző gének mutációja ugyanazt a fenotípust okozza) ismerete meghatározó jelentőségú, hiszen a keresési/szürési stratégiánkat alapvetően ezek határozzák meg.

\section{Funkcionális vizsgálat}

A diagnosztikai folyamat következő kritikus és nélkülözhetetlen állomása a kiszưrt szekvenciavariáns betegségokozó hatásának funkcionális bizonyítása. Ez a gyakorlatban azt jelenti, hogy ma már a legmodernebb „száraz” (szekvenáló-) laboratóriumok sem létezhetnek „nedves” laboratóriumok nélkül, ahol a hagyományos molekuláris genetikai vizsgálómódszerekkel (például Western blot, transzfekció stb.) lehetőség van a szekvenciavariáns kóroki szerepének igazolására. Ez különösen fontos PID esetében, hiszen az eddig azonosított PID-betegségi gének több mint $20 \%$-a egy beteget érintő vizsgálatokból származik, ami a talált genetikai eltérés validálását jelentősen megnehezíti. Egy beteget érintő új betegségi gén esetén nincs összehasonlítási alap, nincs másik beteg, akivel a talált klinikai, immunológiai vagy genetikai eltéréseket összevethetnénk. A legegyszerúbb a helyzet akkor, ha a génszekvenálás eredménye egy korábban már leírt, igazolt patogenitású szekvenciaeltérést mutat. A bizonyítási folyamat lehet tehát egyszerü (ez a ritkább), de szükségessé teheti jelentős mennyiségü és időigényü további experimentális vizsgálat elvégzését is, amíg a szekvenálástól eljutunk a végső bizonyításig és a genetikai diagnózis kimondásához. A vizsgálatok során igazolnunk kell, hogy a szekvenciavariáns megszünteti, csökkenti vagy megváltoztatja a géntermék expresszióját vagy funkcióját. Az első lépés minden esetben a feltételezett 
variáns hatásának vizsgálata a fehérjeexpresszióra. A csökkent fehérjekifejeződés erős bizonyíték a variáns patogenitása mellett, de nem szükséges vagy elégséges annak kimondásához. A fehérjeexpressziós vizsgálatokat követően a variáns funkcionális hatását egy-egy sejttípusban is demonstrálni kell. Végül, de nem utolsósorban igazolni kell, hogy a megváltozott génfunkció hatással (lehet pozitív, nem csak negatív) van egy PID-hez kapcsolódó biológiai folyamatra. Ha ezek a sejtszintú kísérletek sem szolgáltatnak szilárd bizonyítékot, akkor állatmodelles kísérleteket kell végezni az ok-okozati összefüggések kimutatására. Az egérkísérletek során azonban figyelembe kell venni, hogy a laboratóriumi egerek nem feltétlenül ideális betegségmodellek, mivel beltenyésztettek és erősen kontrollált körülmények között tartottak. Az általánossal gondolttal ellentétben tehát új betegségi gének és/vagy új szekvenciavariánsok esetében a molekuláris genetikai diagnosztika nem ér véget a szekvenálással és a genetikai eltérés(ek) azonosításával, hanem hosszú, éveket is igénybe vevő bizonyítási folyamat következik, amíg a talált genetikai eltérés patogenitása bizonyítást nyer.

\section{Génpanel- versus teljesgenom- versus teljesexom-szekvenálás}

PID esetében az NGS-alapú technikák - mint a génpanel-szekvenálás, a WES és a WGS - mind a kutatási, mind a diagnosztikai célokra ideálisnak mondhatók, mivel a genetikai pleiotropia (egy adott gén mutációja több különböző fenotípust eredményez) és a genetikai heterogenitás (különböző gének mutációja ugyanazt a fenotípust okozza) különösen jellemzi ezt a betegségcsoportot. Az NGS-technikák azért is célravezetőek, mert még mindig nagy az ismeretlen genotípusú PID-fenotípusok száma, és hasonlóan sok klinikai és/vagy immunológiai fenotípus esetében még nem is sejtjük, hogy a háttérben egy PID-gén mutációja áll [17, 18].

\section{Génpanel-szekvenálás}

A génpanel-szekvenálás elviekben egy gyors, első vonalbeli diagnosztikai tesztnek tünik. Előnye, hogy jelenleg még kevésbé költséges, mint a WES és a WGS, és minimális a véletlen leletek kockázata, hiszen előre meghatározott a vizsgálni kívánt génpaletta (3. ábra). A génpanel-szekvenálás kutatási célokra nem ideális módszer, és számos ok miatt PID-ben a diagnosztikai célú felhasználása sem ideális. 2010 óta átlagosan tíz új PID-betegségi gént fedeztek fel évente. A panelszekvenálás ezzel az óriási „tempóval” nem tud lépést tartani, hiszen ez a panelek folyamatos frissítését igényelné. A génpanelek használata kizárja az új betegségi gének felfedezését is, PID-ben ugyanakkor magas azon betegek száma, akiknél a WES vagy a WGS később új betegségi gént igazol. Félrevezető lehet tehát, ha a klinikus csak a panelben szereplő génekre fókuszál, miközben a valódi betegségi gének hiányoznak az adott panelből. További hátrány, hogy nincs lehetőség a célterületen kívüli keresésre abban az esetben, ha a vizsgálat mutációt nem igazol. Nem közömbös az sem, hogy a szekvenálás fajlagos költsége WES és WGS esetében folyamatosan csökken, a génpanel-szekvenálásé viszont növekszik. Bár a panelszekvenálás hatékonysága a vizsgált betegpopulációtól és az alkalmazott panelektől függően változhat, nagy esetszámú vizsgálatok alapján a panelszekvenálás a betegek mindössze 15\%-ában eredményez genetikai diagnózist [19, 20].

\section{WES és WGS}

A PID-kutatás és diagnosztika számára jelenleg a leginkább költséghatékony eljárást a WES jelenti, ugyanakkor a WGS több előnyt kínál. A WGS-nek egyértelmű technikai előnyei vannak a WES-sel szemben, mivel egységes lefedést biztosít, és képes érzékelni az intron és intergenikus mutációkat (3. ábra). Fontos, hogy a WGS a CNV- (copy number variation, kópiaszám-variáció) régiókat is felismeri. Az ember egyes DNS-szakaszai nem feltétlenül két kópiában fordulnak elő, bizonyos DNSszegmensek kópiaszámában a populáción belül komoly változékonyság lehet. A kópiaszám-változás jelenthet növekedést, duplikáció révén, vagy csökkenést is, deletiók révén. A CNV különösen gyakori az immunrendszer és az agy fejlődésében szerepet játszó génekben. A WGS további előnye, hogy a vizsgálat eredményeként a teljesgenom-szekvencia rendelkezésre áll, így specifikus elemzőszoftverek segítségével virtuálisan a kezdeti teljesgenom-vizsgálat „panelszerü elemzésre” vagy „exomszerü elemzésre” konvertálható.

A WES esetében fontos, hogy a DNS-templát exonokban gazdag legyen, míg ez értelemszerüen WGS esetében nem szükségszerü (3. ábra). Ez egyben magában rejti a WES egyik legnagyobb hibalehetőségét is, hiszen az úgynevezett exondúsítás nem teljesen homogén folyamat az összes exon esetében, ami az eredményeket torzíthatja. A PID-esetek túlnyomó részében a WES elegendő diagnosztikai vizsgálat, és felesleges a WGS-nek, vagyis a teljesgenom-szekvenciának a meghatározása. Ennek egyik oka az, hogy az elmúlt évtizedek humángenetikai kutatásai azt mutatják, hogy a monogénes betegségek esetében a mutációk túlnyomórészt az exomban találhatók, és még inkább annak kódoló régiójában [21]. A másik ok az, hogy az exom az egész genom legkonzerváltabb régiója, vagyis az exomon kívül, a kevésbé konzervált régiókban elhelyezkedő szekvenciavariánsok nem valószínü, hogy megzavarják egy gén expresszióját és múködését, ami azt jelenti, hogy itt ritkább a patogén variánsok előfordulása. A WES egyik hátránya, hogy az RNS-géneket jellemzően kevésbé fedi le, mint a WGS [22]. Fontos annak ismerete is, hogy vannak olyan ismert gének, amelyeket a WES nem érzékel, például azért, mert mélyen az intronban helyezkednek el. Ennek 
eklatáns példája a X-kromoszómához kötötten öröklődő dermatopathia pigmentosa reticularis, amelynek génjét két évtizedes kutatómunka után végül WGS-sel sikerült azonosítani, mivel a mutáció mélyen az intronban helyezkedett el [23]. Egy negatív WES-lelet tehát nem zárja ki egyértelmúen a mutáció lehetőségét.

A WGS jelenleg drágább vizsgálat, mint a WES, de remény van arra, hogy a költségek további csökkenésével a WES-hez hasonló költségkategóriába kerüljön. A genetikai technológia gyorsan fejlődő területén így a WES várhatóan átadja majd a helyét a WGS-nek, amely jobb lefedettséget biztosít a kódoló és a nem kódoló DNSszakaszokra, az intronokra és a szabályozó DNS-régiókra egyaránt.

\section{A molekuláris genetikai vizsgálatok jelentősége PID-ben}

Az NGS egyre szélesebb körű alkalmazásának köszönhetően jelentősen nőtt a diagnosztizált PID-betegek száma. Az 1. ábra szemléletesen mutatja az NGS kedvező hatását a PID-betegségek diagnosztikájára. Az NGS többek között hozzájárult a monogénes hátterü hypogammaglobulinaemiák és az úgynevezett immundiszregulációs szindrómák nagyobb számban történő felismeréséhez, és a módszer segítségével számos olyan PID-betegségben is sikerült a patomechanizmust tisztázni, amelyben a fenotípust egyetlen, jól meghatározott kórokozóval vagy kórokozócsoporttal szembeni fokozott fogékonyság jellemzi. A részben vagy teljes egészében az NGS-technikának köszönhetően felismert PIDgéneket és az általuk meghatározott fenotípust az 1 . táblázat foglalja össze $[23,24]$. Az NGS-diagnosztika elterjedésének egyik legfontosabb hozadéka, hogy lehetôség nyílt addig ismeretlen, új PID-betegségi gének felfedezésére. A módszer lehetőséget teremtett arra, hogy egyetlen vagy kevés beteget érintő immunhiányos állapotok esetében is genetikai diagnózis születhessen.

A genetikailag igazolt esetek számának növekedésével a fenotípusspektrum is könnyebben vizsgálható. Az NGS-módszernek köszönhetően ma már tudjuk, hogy a PID-fenotípus meglepően heterogén, így például a betegségi tünetek még azonos génmutációt hordozó betegekben is eltérőek lehetnek, akár ugyanazon családon belül. A fenotípus markáns heterogenitásának oka ugyanazon gént érintő mutációk esetében lehet az, hogy az adott gén különböző mutációi nagyon eltérő hatást gyakorolnak a fehérje múködésére. Ennek egyik iskolapéldája az X-kromoszómához kötötten, recesszíven öröklődő Wiskott-Aldrich-szindróma kialakulásáért felelős gén, a WAS. Nullmutációk vagy úgynevezett funkcióvesztő (loss-of-function [LOF]) mutációk esetében a klasszikus triásszal (thrombocytopenia, ekcéma és visszatérő fertőzések) jellemzett klinikai képet látjuk [25]. Ezzel szemben úgynevezett funkciónyerő (gain-of-function [GOF]) mutációk esetén a fenotípust neutropenia jellemzi, thrombocytaérintettség és infekciók nélkül [26]. A feno- típusos sokszínúség hátterében az autoszomális domináns $(\mathrm{AD})$ immunhiány-betegségek nagyobb arányú felismerése is állhat, amelyek igen gyakran változó penetranciájúak. Az NGS-t megelőzó érában az autoszomális recesszív (AR) öröklődésű PID-betegségek előfordulási gyakorisága körülbelül a négyszerese volt az $\mathrm{AD}$ öröklődésű formáknak, hiszen a klasszikus molekuláris genetikai vizsgálómódszerekkel egy AR eltérés sokkal könnyebben diagnosztizálható. Az NGS térhódításával azonban folyamatosan növekszik az AD öröklődésű felismert PID-betegségek száma, mert ez a módszer lehetővé teszi a mutációk felismerését egy vagy kisszámú nem rokon, de azonos fenotípusú beteg esetében is [27]. Dominás öröklődésmenet esetén (az autoszomális és az X-hez kötött formákban egyaránt) a LOF és a GOF mutációk mellett előfordulhat haploinsufficientia is, amikor az egyetlen fennmaradó funkcionális allél nem képes elegendő génterméket (jellemzően fehérjét) biztosítani a vad (egészséges) fenotípus megőrzéséhez, ami a betegség kialakulásához vezethet. A fenotípust tovább színezhetik az úgynevezett hipomorf mutációk (domináns és recesszív egyaránt lehet), amelyekről régóta ismert, hogy enyhébb fenotípust vagy a betegség késői kialakulását idézhetik elő. Ez úgy lehetséges, hogy a gén által kódolt fehérjéből kevesebb termelődik, vagy a fehérje szerkezete módosul, így funkciója csökken a vad típuséhoz képest, de teljesen nem szúnik meg. Kiváló példa erre a RAGl, amelynek nullmutációi klasszikus SCID-et okoznak, a T- és a B-sejtek teljes hiányával. Néhány RAGlmutáció esetében ugyanakkor Omenn-szindróma, granulomatosus betegség, autoimmun manifesztációk, illetve gyulladásos osteomyelitis megjelenése észlelhető [24]. A mutációk funkcionális következményeinek megértését tovább bonyolítja az a tény, hogy ugyanaz a mutáció különböző sejtvonalakban különböző következményekkel járhat. Ugyanakkor néhány mutáns gén szöveti és szervi expressziója rendkívül széles, a fenotípusra mégis a nagyon szúk klinikai spektrum jellemző. Az NGS-nek köszönhetően meglepő gyakorisággal kerülnek felismerésre úgynevezett de novo mutációkat hordozó, negatív családi anamnézisú betegek, akikre nagyon súlyos vagy rendkívül szokatlan klinikai kép jellemző, korai megjelenéssel és gyakran halálos kimenetellel. Az NGS-érát megelőzően ezeknek a betegeknek a nagy része is diagnosztizálatlan maradt, így a PID-fenotípus skáláján nagy részük korábban nem volt reprezentálva.

A PID-betegségek száma olyan gyorsan növekszik, hogy szükségessé vált a korábbi terminológia felülvizsgálata is. A PID, illetve a PIDD (PID disorders, PID-betegségek) rövidítéseken ma már az immunhiány-betegségek egy szúkebb csoportját értjük, amelyekben a betegség fó megnyilvánulása a fertőzésekre való fogékonyság. Ugyanakkor az immundiszregulációs szindrómák növekvő száma miatt, amelyek magukban foglalják az autoinflammatiós szindrómákat $[28,29]$ és az interferonopathiákat is, egy sokkal tágabb értelmű terminoló- 







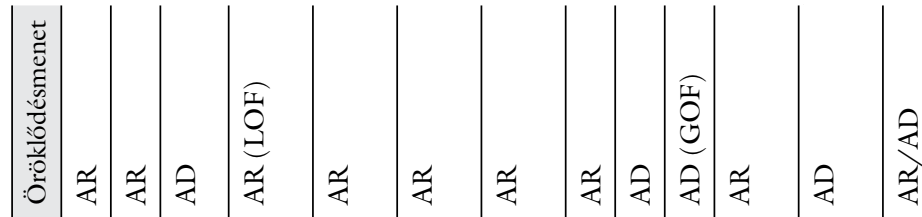

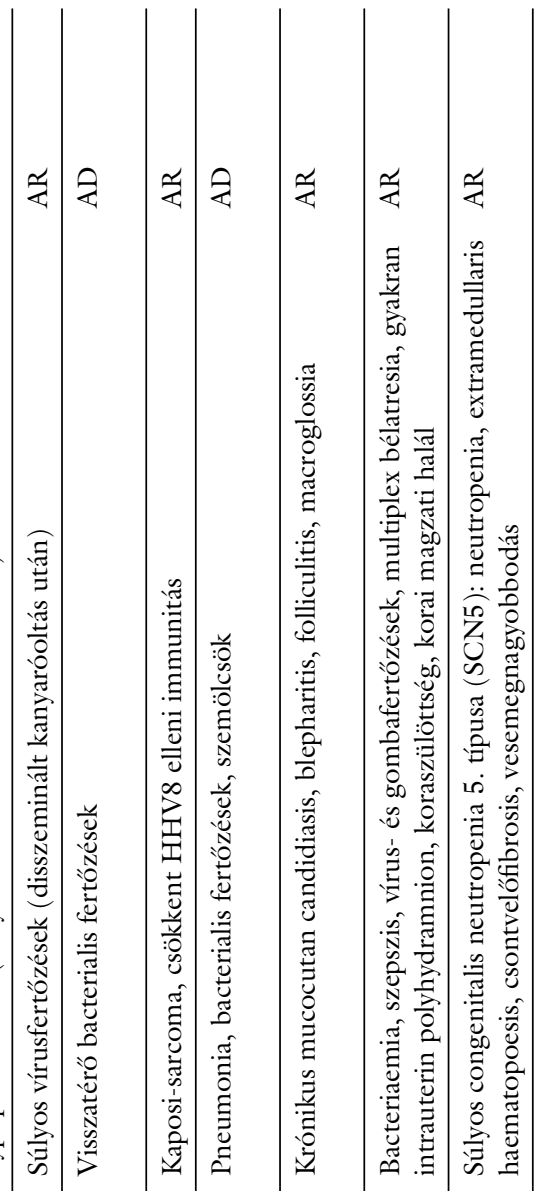

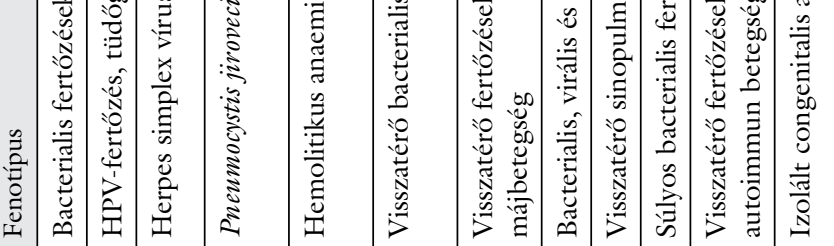

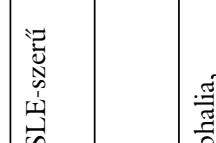

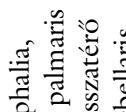

觉

.ํํำ

每:

里

|

齐

ने

语 云

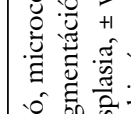

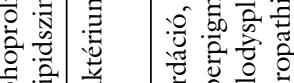

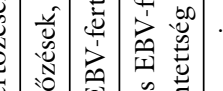

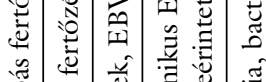

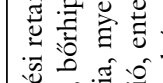

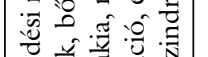

㻤

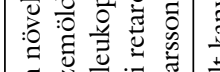

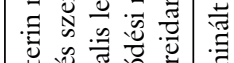

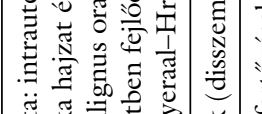

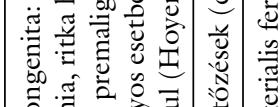

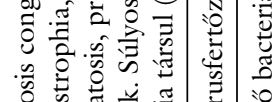

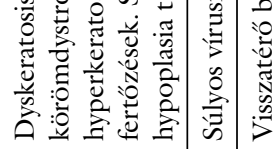

ज्ञ

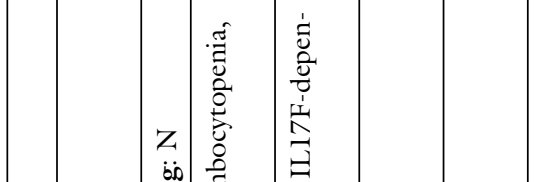

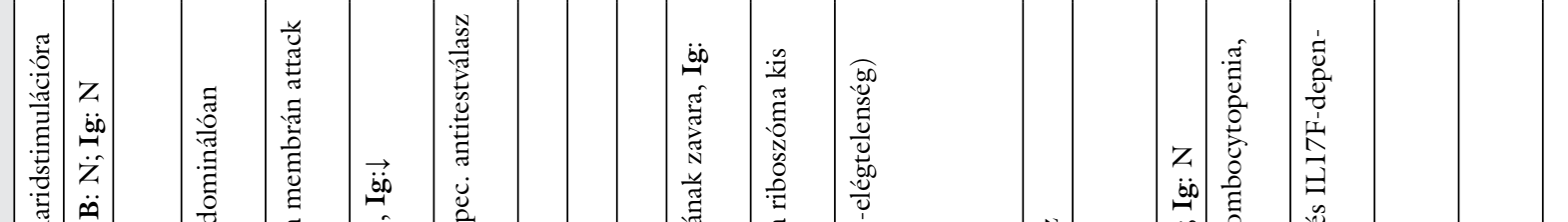

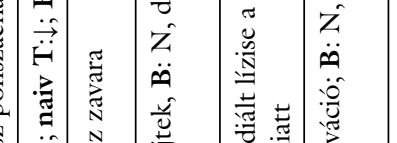

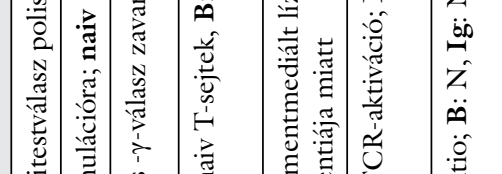

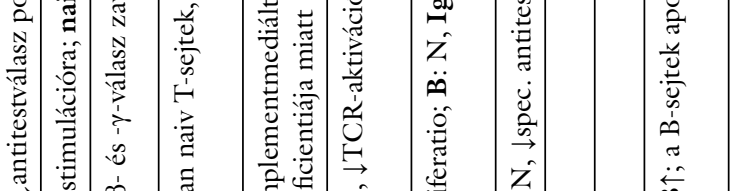

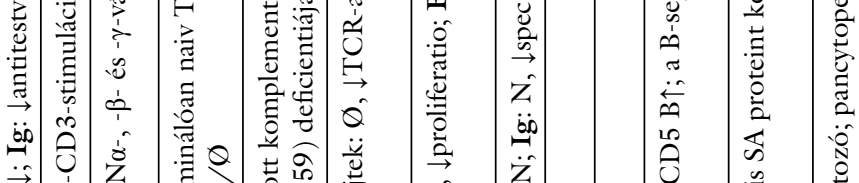

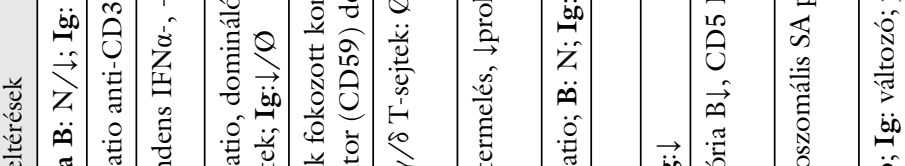

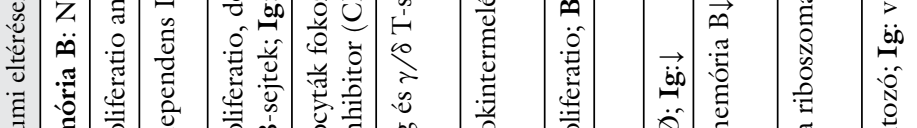

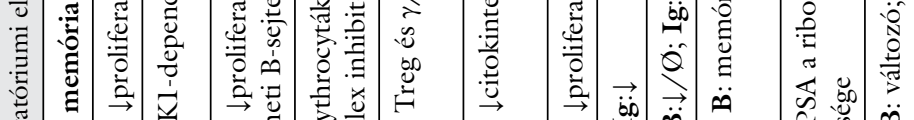

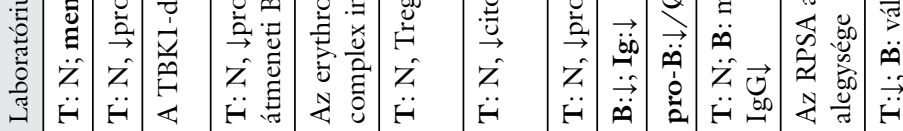

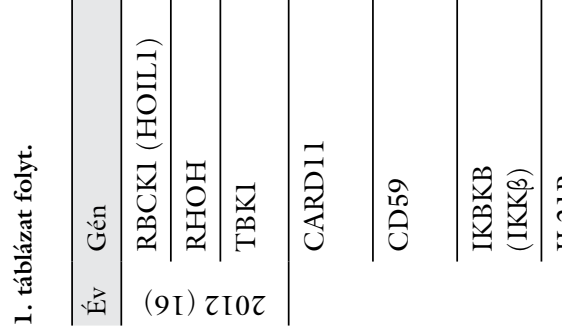

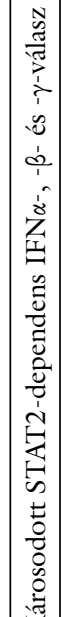

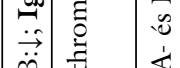

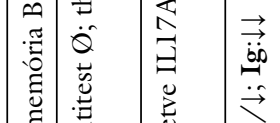

$\dot{z}$

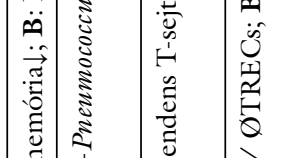

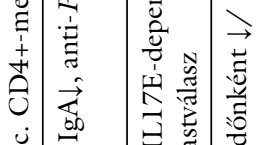

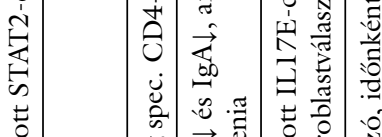

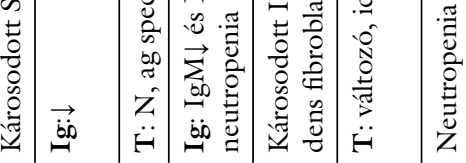

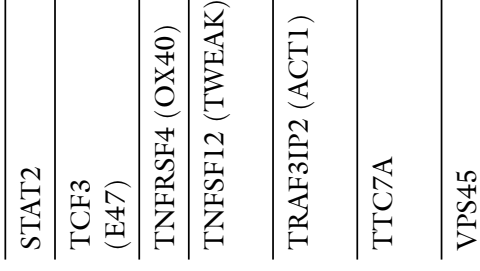

$(\angle \mathrm{I}) \varepsilon \mathrm{I} 0 \tau$ 


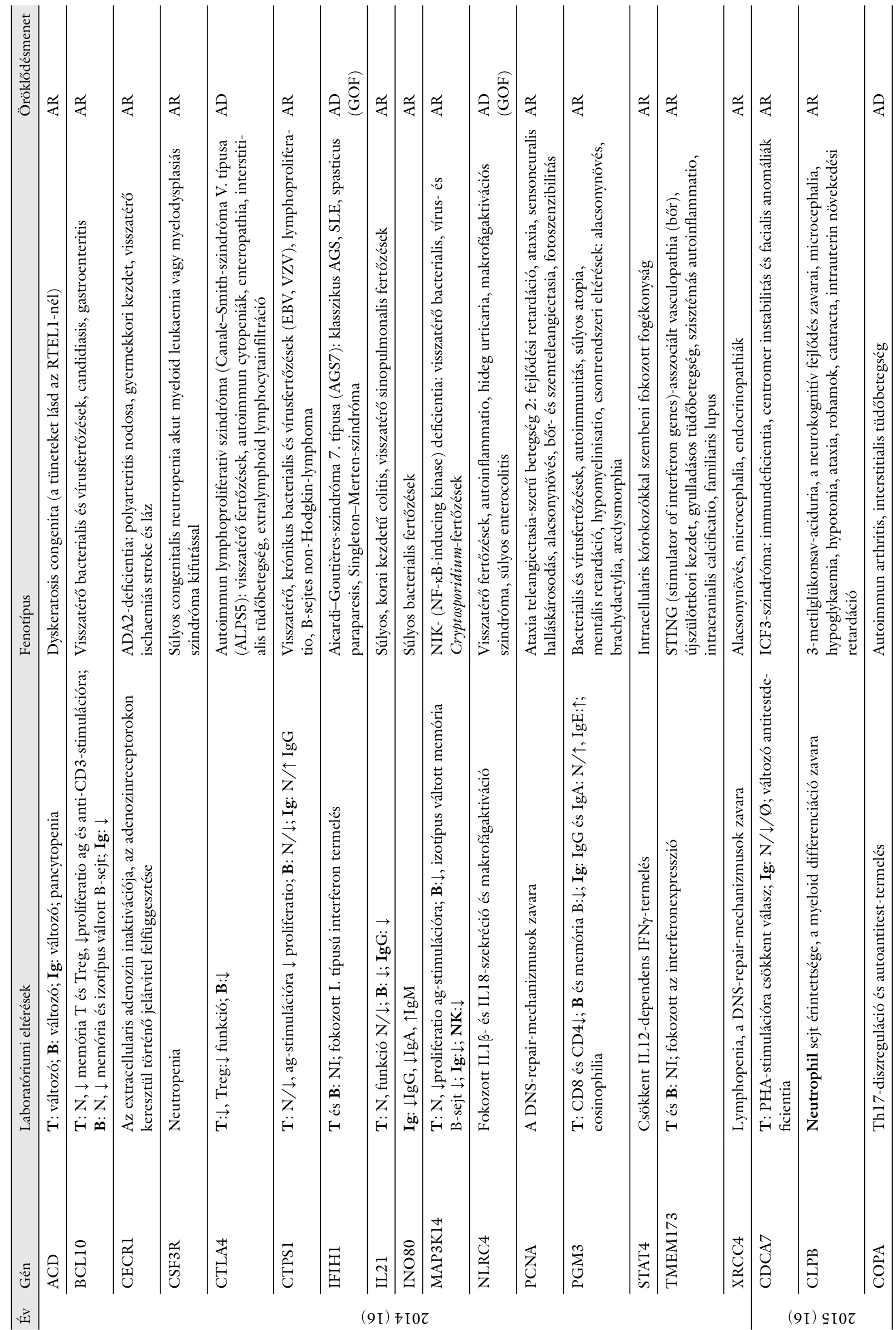




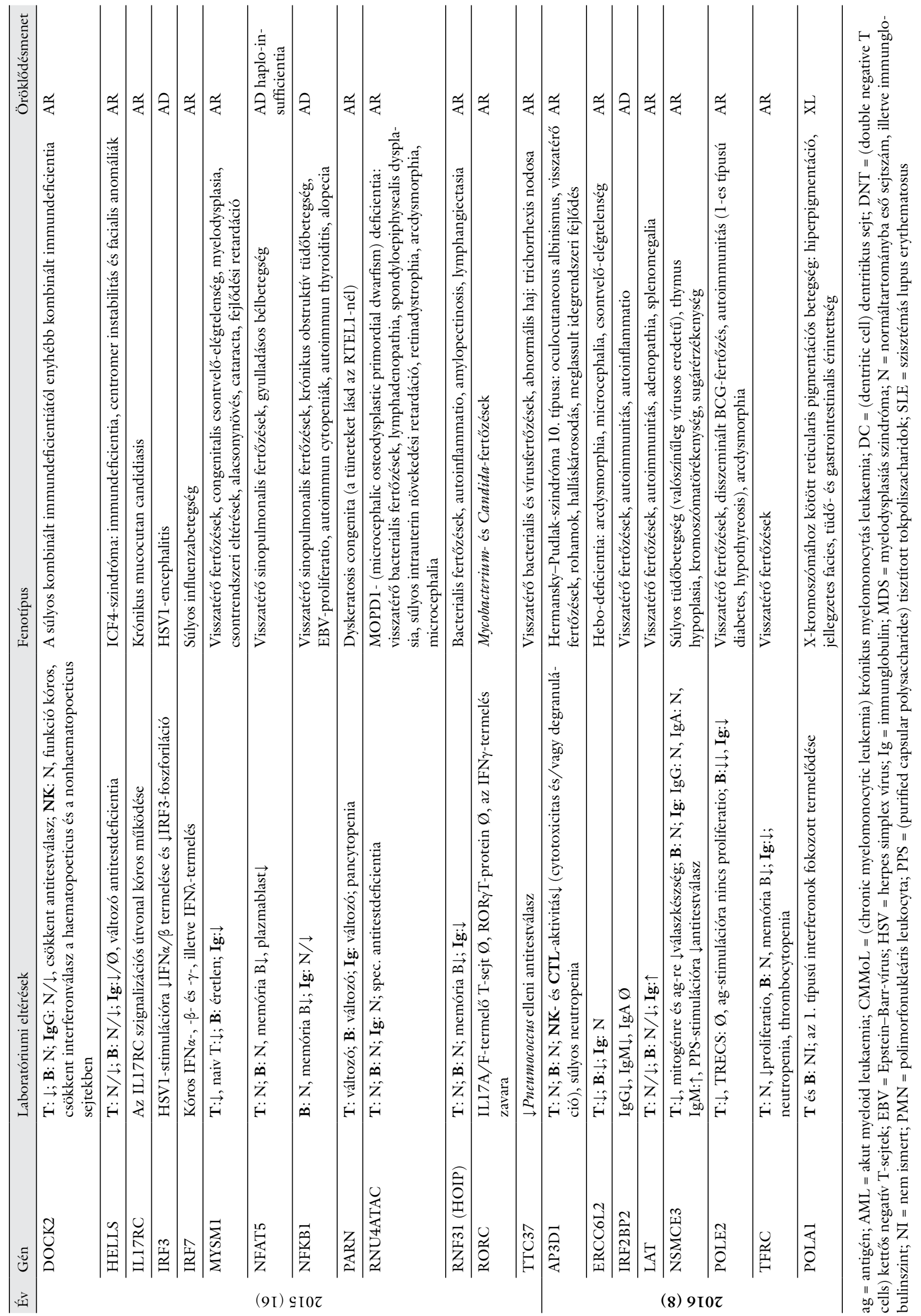


gia, az úgynevezett „inborn errors of immunity” (az immunitás veleszületett hibái) kifejezés alkalmazása javasolt.

PID esetén a génszintű diagnosztika a következők miatt nem nélkülözhető:

1. A molekuláris genetikai vizsgálatok megerősítik a feltételezett diagnózist, ami különösen fontos, ha a laboratóriumi leletek és a klinikai kép a megszokottól eltérő, szokatlan.

2. A molekuláris genetikai diagnózis végleges diagnózis, így a PID-betegek esetében sajnos gyakran tapasztalt elhúzódó és céltalan kivizsgálások, illetve a tartós „diagnózisnélküliség” okozta bizonytalanság végére pont tehető.

3. A genetikai vizsgálattal egy potenciálisan halálos kimenetelü betegség már a tünetek megjelenése előtt felismerhető, ami lehetővé teszi az időben történő beavatkozást. A korai, biztos diagnózis lehetővé teszi a fertőzések kialakulásának megelőzését és a korai adekvát immunterápiát, így csökkenthető a szövődmények és a maradandó szervi károsodások kialakulásának veszélye.

4. A PID által érintett családokban lehetőség nyílik a genetikai tanácsadásra, amely csak akkor lehet releváns, ha a genetikai diagnózis már a kezünkben van. A hordozóállapot kiszúrése és a praenatalis diagnosztika óriási jelentőségét a családtervezésben nem kell hangsúlyozni.

5. A genetikai vizsgálatok segítségével tisztázható az immunhiányos betegség patomechanizmusa.

6. Erős genotípus-fenotípus korreláció esetén a molekuláris diagnózis prognosztikai információt nyújthat.

7. Az esetek egy kis részében a molekuláris genetikai vizsgálatok után is maradnak nyitott kérdések, hiszen ugyanaz a fenotípus különböző géndefektusok következménye is lehet, illetve ugyanaz a génmutáció sokszor egy családon belül is teljesen eltérő fenotípust eredményez. A genotípus-fenotípus összefüggések vizsgálatával ugyanakkor más genetikai faktorok és további környezeti tényezők pontos szerepe is tisztázható.

\section{PID-diagnosztika - magyarországi előzmények és helyzetkép}

Magyarországon 2003-ig döntően a humoralis és a cellularis immunválasz felmérésére alkalmas funkcionális, immunkémiai és biokémiai módszereket alkalmazták a primer immunhiány-betegségek diagnosztikájában. A korszerû diagnosztikai feltételek biztosítása azonban szükségessé tette molekuláris genetikai vizsgálómódsze-

2. táblázat A Debreceni Egyetem Infektológiai és Gyermekimmunológiai Tanszékének Molekuláris Genetikai Laboratóriumában diagnosztizált primer immunhiányos betegek genotípusa

\begin{tabular}{|c|c|c|c|c|}
\hline \multirow[t]{2}{*}{ Betegség } & \multicolumn{2}{|l|}{ Mutáns gén (öröklődésmenet) } & \multirow[t]{2}{*}{ A mutáció típusa } & \multirow{2}{*}{$\begin{array}{l}\text { Eset- } \\
\text { szám }\end{array}$} \\
\hline & Nukleotidcsere & Aminosavcsere & & \\
\hline \multicolumn{5}{|c|}{ KOMBINÁLT IMMUNDEFICIENTIÁK (B- ÉS T-SEJT-DEFEKTUSOK) } \\
\hline \multicolumn{5}{|c|}{ T-B+ súlyos kombinált immundeficientia (SCID) } \\
\hline \multirow{3}{*}{$\begin{array}{l}\text { X-kromoszómához kötött SCID } \\
\text { (közös gamma-lánc-deficientia, CD132-de- } \\
\text { ficientia) }\end{array}$} & $\operatorname{IL} 2 R G(\mathrm{XL})$ & & & 4 \\
\hline & c.802G $>\mathrm{C}$ & p.G268R & Missense & 2 \\
\hline & c.295ins $A$ & p.V99fs $X 110$ & Insertio & 2 \\
\hline \multicolumn{5}{|l|}{ T-B-SCID } \\
\hline \multirow[t]{2}{*}{ RAG2-deficientia } & $R A G 2(\mathrm{AR})$ & & & 2 \\
\hline & c.645_646insAC/c.1563delT & p.T215fsX5/p.P422fsX3 & Insertio/deletio & 2 \\
\hline \multicolumn{5}{|c|}{ Kombinált immundeficientia, a SCID-hez képest enyhébb fenotípussal } \\
\hline \multirow{10}{*}{$\begin{array}{l}\text { CD40L-deficientia } \\
\text { (CD154-deficientia) }\end{array}$} & CD40LG (TNFSF5) (XL) & & & 16 \\
\hline & c. $216 \mathrm{C}>\mathrm{A}$ & p.C72X & Nonsense & 2 \\
\hline & $c .430 G>A$ & p.G144R & Missense & 1 \\
\hline & c. $521 \mathrm{~A}>\mathrm{G}$ & p.Q174R & Missense & 2 \\
\hline & c. $654 \mathrm{C}>\mathrm{A}$ & p.C218X & Nonsense & 5 \\
\hline & c. $694 \mathrm{C}>\mathrm{T}$ & p.Q232X & Nonsense & 1 \\
\hline & c.IVS3 + 1G>T & - & Splice site & 1 \\
\hline & c. $58 \mathrm{delA}$ & p.S20fs $X 21$ & Deletio & 2 \\
\hline & c.77_89dell3bp & p. $226 f s X 33$ & Deletio & 1 \\
\hline & c.470delA & p.N157fsX161 & Deletio & 1 \\
\hline \multirow[t]{2}{*}{ DOCK8-deficientia } & $\operatorname{DOCK} 8(\mathrm{AR})$ & & & 2 \\
\hline & dell-14 exons/del8-18 exons & & Nagydeletio & 2 \\
\hline
\end{tabular}


2. táblázat folyt.

\begin{tabular}{|c|c|c|c|c|}
\hline \multirow[t]{2}{*}{ Betegség } & \multicolumn{2}{|l|}{ Mutáns gén (öröklődésmenet) } & \multirow[t]{2}{*}{ A mutáció típusa } & \multirow{2}{*}{$\begin{array}{l}\text { Eset- } \\
\text { szám }\end{array}$} \\
\hline & Nukleotidcsere & Aminosavcsere & & \\
\hline \multicolumn{5}{|c|}{ KOMBINÁLT IMMUNDEFICIENTIÁK SZINDRÓMAJELEKKEL } \\
\hline \multicolumn{5}{|c|}{ Immundeficientia congenitalis thrombocytopeniával } \\
\hline \multirow{10}{*}{$\begin{array}{l}\text { Wiskott-Aldrich-szindróma } \\
\text { (WAS) }\end{array}$} & $W A S(\mathrm{XL})$ & & & 10 \\
\hline & c. $121 \mathrm{C}>\mathrm{T}$ & p.R4lX & Nonsense & 1 \\
\hline & c. $190 \mathrm{~T}>\mathrm{C}$ & p.W64R & Missense & 1 \\
\hline & c. $221 \mathrm{~T}>\mathrm{C}$ & p.F74S & Missense & 1 \\
\hline & c. $257 \mathrm{G}>\mathrm{A}$ & p.R86H & Missense & 1 \\
\hline & c. $397 \mathrm{G}>\mathrm{T}$ & p.E133X & Nonsense & 2 \\
\hline & c.106-108delTT & p.F36X & Nonsense & 1 \\
\hline & c. $278-279 \mathrm{delGT}$ & p.G93fsX121 & Deletio & 1 \\
\hline & c. $1075 \mathrm{delC}$ & p.P359fsX444 & Deletio & 1 \\
\hline & c.IVS9 + 1G>A & - & Splice site & 1 \\
\hline \multicolumn{5}{|c|}{ Kromoszómatörékenységgel és/vagy DNS-repair-defektussal társuló immundeficientiák } \\
\hline \multirow{2}{*}{$\begin{array}{l}\text { Nijmegen breakage szindróma } \\
\text { (NBS) }\end{array}$} & $N B N(\mathrm{AR})$ & & & 3 \\
\hline & c.657_661del5bp/c.657_661del5bp & $\begin{array}{l}\text { p.K219fsX234/p. } \\
\text { K219fsX234 }\end{array}$ & Deletio & 3 \\
\hline \multicolumn{5}{|c|}{ Thymusdeficientia egyéb társuló congenitalis anomáliával } \\
\hline \multirow[t]{2}{*}{ Di George/velocardiofacialis szindróma } & 22-es kromoszóma (AD) & & & 1 \\
\hline & c.del22q11.2 & & Nagydeletio & 1 \\
\hline \multicolumn{5}{|l|}{ Immunoosseous dysplasiák } \\
\hline \multirow{2}{*}{$\begin{array}{l}\text { Porc-haj hypoplasia } \\
(\mathrm{PHH})\end{array}$} & $R M R P(\mathrm{AR})$ & & & 1 \\
\hline & $\begin{array}{l}\text { dupTACTACTCTGTGAAat-12 } \\
\text { (TATA boksz és a transzkripció } \\
\text { kezdőhelye között)/c.236A>G }\end{array}$ & $\begin{array}{l}\text { Az RMRP a mitokondriá- } \\
\text { lis RNS feldolgozásában } \\
\text { szerepet játszó endoribo- } \\
\text { nukleáz RNS komponen- } \\
\text { sét kódolja }\end{array}$ & Duplikáció & 1 \\
\hline \multicolumn{5}{|l|}{ Hiper-IgE-szindróma (HIES) } \\
\hline \multirow{7}{*}{$\begin{array}{l}\text { Autoszomális domináns HIES (STAT3 } \\
\text { deficientia, Jób-szindróma) }\end{array}$} & STAT3 (AD LOF) & & & 11 \\
\hline & c. $994 \mathrm{C}>\mathrm{T}$ & p.H332Y & Missense & 3 \\
\hline & c. $1144 \mathrm{C}>\mathrm{T}$ & p.R382W & Missense & 4 \\
\hline & c. $1825 \mathrm{~A}>\mathrm{G}$ & p.R609G & Missense & 1 \\
\hline & c. $1865 \mathrm{C}>\mathrm{T}$ & p.T622I & Missense & 1 \\
\hline & c. $1909 \mathrm{G}>\mathrm{T}$ & p.V637L & Missense & 1 \\
\hline & c.IVS $8-3 C>G$ & - & Splice site & 1 \\
\hline \multicolumn{5}{|c|}{ Dyskeratosis congenita (DKC), myelodysplasia, rövid telomerek } \\
\hline \multirow{2}{*}{$\begin{array}{l}\text { Dyskerindeficientia okozta } \\
X L-D K C\end{array}$} & $D K C I(\mathrm{XL})$ & & & 1 \\
\hline & c.IVS2-5C>G & - & Splice site & 1 \\
\hline \multicolumn{5}{|c|}{ ANTITESTDEFICIENTIÁK } \\
\hline \multicolumn{5}{|c|}{ Agammaglobulinaemia csökkent B-sejt-számmal vagy B-sejt-hiánnyal } \\
\hline \multirow{4}{*}{$\begin{array}{l}\text { X-kromoszómához kötött agammaglobuli- } \\
\text { naemia } \\
\text { (XLA, BTK-deficientia) }\end{array}$} & $B T K(\mathrm{XL})$ & & & 18 \\
\hline & c. $115 \mathrm{~T}>\mathrm{A}$ & p.Y39N & Missense & 2 \\
\hline & c. $1025 \mathrm{C}>\mathrm{T}$ & p.R288W & Missense & 1 \\
\hline & c. $1064 \mathrm{~T}>\mathrm{A}$ & p.I355N & Missense & 2 \\
\hline
\end{tabular}


2. táblázat folyt.

\begin{tabular}{|c|c|c|c|c|}
\hline \multirow[t]{2}{*}{ Betegség } & \multicolumn{2}{|c|}{ Mutáns gén (öröklődésmenet) } & \multirow[t]{2}{*}{ A mutáció típusa } & \multirow{2}{*}{$\begin{array}{l}\text { Eset- } \\
\text { szám }\end{array}$} \\
\hline & Nukleotidcsere & Aminosavcsere & & \\
\hline \multirow{13}{*}{$\begin{array}{l}\text { X-kromoszómához kötött agammaglobuli- } \\
\text { naemia } \\
\text { (XLA, BTK-deficientia) }\end{array}$} & c. $1087 \mathrm{C}>\mathrm{T}$ & p.Q363X & Nonsense & 1 \\
\hline & c. $1184 \mathrm{G}>\mathrm{A}$ & p.W395X & Nonsense & 1 \\
\hline & c. $1337 \mathrm{~T}>\mathrm{C}$ & p.L402P & Missense & 1 \\
\hline & c. $1574 \mathrm{G}>\mathrm{A}$ & p.R525Q & Missense & 1 \\
\hline & c. $1631 \mathrm{G}>\mathrm{C}$ & p.R544T & Missense & 1 \\
\hline & c. $1699 \mathrm{G}>\mathrm{A}$ & p.E567K & Missense & 1 \\
\hline & c. $1846 \mathrm{C}>\mathrm{G}$ & p.L616V & Missense & 1 \\
\hline & c. $1952 \mathrm{~T}>\mathrm{G}$ & p.I651S & Missense & 1 \\
\hline & c.89_101dell3 bp & p.F30fsX52 & Deletio & 1 \\
\hline & c. $472 \_475 \mathrm{delACAG}$ & p.T158fsX174 & Deletio & 1 \\
\hline & c.1777delC & p.L593fs X649 & Deletio & 1 \\
\hline & c.IVS8-1G>A & - & Splice site & 1 \\
\hline & c.IVS14 + 5G $>A$ & - & Splice site & 1 \\
\hline
\end{tabular}

Hiper-IgM-szindróma (HIGM), súlyosan csökkent IgG és IgA, normál- vagy emelkedett IgM, normál-B-sejtszám

AID- (aktivációindukált citidin-dezami-

náz) deficientia

\begin{tabular}{lllr}
$A I C D A$ & & & 7 \\
\hline c. $172 \mathrm{AR}>\mathrm{A} / \mathrm{c} .259 \mathrm{~T}>\mathrm{C}$ & p.E57K $/$ p.C87R & Missense $/$ missense & 1 \\
\hline c. $259 \mathrm{~T}>\mathrm{C} / \mathrm{c} .259 \mathrm{~T}>\mathrm{C}$ & p.C87R $/$ p.C87R & Missense $/$ missense & 2 \\
\hline c. $259 \mathrm{~T}>\mathrm{C} / \mathrm{c} .338 \mathrm{~T}>\mathrm{C}$ & p.C87R $/$ p.L113P & Missense $/$ missense & 4
\end{tabular}

\section{IMMUNDISZREGULÁCIÓS SZINDRÓMÁK}

Regulatorikus-T-sejt-deficientia

IPEX-szindróma $\quad$ FOXP3 (XI)

(immundiszreguláció, polyendocrinopathia,

enteropathia, $X$-linked

Autoimmunitás lymphoproliferatióval vagy a nélkül

APECED-szindróma

AIRE (AR vagy $\mathrm{AD})$

\begin{tabular}{|c|c|c|c|}
\hline AIRE (AR vagy AD) & & & \\
\hline c. $769 \mathrm{C}>\mathrm{T} / \mathrm{c} .769 \mathrm{C}>\mathrm{T}$ & p.R257X/p.R257X & Nonsense/nonsense & 7 \\
\hline c.769C>T/c.44_66dup23bp & p.R257X/p.R15fsX19 & Nonsense/duplikáció & 1 \\
\hline c.769C >T/c.965_977dell3bp & p.R257X/p.L323fsX373 & Nonsense/deletio & 1 \\
\hline c.769C $>\mathrm{T} /$ c.1148ins $G$ & p.R257X/p.E383fsX423 & Nonsense/insertio & 1 \\
\hline c.769C $>\mathrm{T} / \mathrm{c} .1344 \mathrm{delC}$ & p.R257X/p.C449fsX479 & Nonsense/deletio & 2 \\
\hline c.IVS9 + 6G>A/c.1411C>T & $-/ \mathrm{p} \cdot \mathrm{R} 47 \mathrm{lC}$ & Splice site/missense & 1 \\
\hline
\end{tabular}

(APS1, autoimmun polyendocrinopathia,

candidiasis, ectodermalis dystrophia)

Autoimmun lymphoproliferativ szindróma (ALPS, Canale-Smith-szindróma)

ALPS-FASLG

(ALPS Ib)

\begin{tabular}{|c|c|c|c|}
\hline FASLG (CD95L) (AR) & & & 3 \\
\hline$c .776 T>G / v t$ & $p . I 259 R / v t$ & Missense & 1 \\
\hline c.335_443dello9bp/vt & p.G112fs $X 151 / v t$ & $\begin{array}{l}\text { Deletio } \\
\text { (a 4. exon deletiója) }\end{array}$ & 1 \\
\hline c.38ins A/vt (domináns negatív) & p.T13fsX17/vt & Insertio/vt & 1 \\
\hline
\end{tabular}

EBV iránti fogékonyság és lymphoproliferativ állapotok

X-kromoszómához kötött lymphoproliferativ SH2DIA (XL)

szindróma

(XLP, SH2DIA-deficientia, SAP-deficien-

tia, XLPI)

\begin{tabular}{lllr}
\hline c. $47 \mathrm{G}>\mathrm{A}$ & p.G16D & Missense & $\mathbf{1 4}$ \\
\hline c. $92 \mathrm{~T}>\mathrm{C}$ & p.L31P & Missense & 4 \\
\hline c. $102 \mathrm{C}>\mathrm{G}$ & p.S34R & Missense & 4 \\
\hline c. $125 \mathrm{G}>\mathrm{A}$ & p.C42Y & Missense & 2 \\
\hline c.IVS1 $+5 G>A$ & - & Splice site & 2 \\
\hline
\end{tabular}


2. táblázat folyt.

\begin{tabular}{|c|c|c|c|c|}
\hline \multirow[t]{2}{*}{ Betegség } & \multicolumn{2}{|l|}{ Mutáns gén (öröklődésmenet) } & \multirow[t]{2}{*}{ A mutáció típusa } & \multirow{2}{*}{$\begin{array}{l}\text { Eset- } \\
\text { szám }\end{array}$} \\
\hline & Nukleotidcsere & Aminosavcsere & & \\
\hline \multicolumn{5}{|l|}{ PHAGOCYTADEFEKTUSOK } \\
\hline \multicolumn{5}{|l|}{ Congenitalis neutropeniák } \\
\hline \multirow{5}{*}{$\begin{array}{l}\text { Elasztázdeficientia } \\
\text { (severe congenital neutropenia 1, SCNI) }\end{array}$} & \multicolumn{2}{|l|}{$E L A N E(E L A 2)(\mathrm{AD})$} & & 6 \\
\hline & Promoter $-199 C>A$ & - & - & 3 \\
\hline & c. $182 \mathrm{C}>\mathrm{T}$ & p.A61V & Missense & 1 \\
\hline & c. $377 \mathrm{C}>\mathrm{T}$ & p.S126L & Missense & 1 \\
\hline & c.IVS4 + IG >A & - & Splice site & 1 \\
\hline \multicolumn{5}{|l|}{ A motilitás zavarai } \\
\hline \multirow[t]{3}{*}{ Shwachman-Diamond-szindróma (SDS) } & \multicolumn{2}{|l|}{$S B D S(\mathrm{AR})$} & & 2 \\
\hline & c. $362 \mathrm{~A}>\mathrm{C} / \mathrm{c} .523 \mathrm{C}>\mathrm{T}$ & p.N121T + p.R175W & Missense/missense & 1 \\
\hline & c.IVS2 $+2 \mathrm{~T}>\mathrm{C} /$ del $872 \mathrm{bp}$ incl. exon 3 & -/872 bázispár deletiója & Splice site/nagydeletio & 1 \\
\hline \multicolumn{5}{|c|}{ A respiratorikus burst defektusai } \\
\hline \multirow{7}{*}{$\begin{array}{l}X \text {-kromoszómához kötött krónikus } \\
\text { granulomás betegség (CGD [chronic } \\
\text { granulomatous disease], gp } 91^{\text {phox }} \\
\text { CYBB-deficientia) }\end{array}$} & \multicolumn{2}{|l|}{$C \Upsilon B B(\mathrm{XL})$} & & 8 \\
\hline & c. $283 \mathrm{C}>\mathrm{T}$ & p.R91X & Nonsense & 1 \\
\hline & c. $793 \mathrm{C}>\mathrm{T}$ & p.Q261X & Nonsense & 2 \\
\hline & c. $880 \mathrm{C}>\mathrm{T}$ & p.R290X & Nonsense & 1 \\
\hline & c. $967 \mathrm{C}>\mathrm{T}$ & p.Q323X & Nonsense & 1 \\
\hline & c.1169 C>T & p.P390L & Missense & 1 \\
\hline & 1-10. exon deletiója* & 1-10. exon deletiója & Nagydeletio & 2 \\
\hline \multicolumn{5}{|c|}{ AZ IMMUNITÁS INTRINSZIK ÉS VELESZÜLETETT ZAVARAI } \\
\hline \multicolumn{5}{|c|}{ Epidermodysplasia verruciformis (HPV) } \\
\hline \multirow{2}{*}{$\begin{array}{l}\text { WHIM- } \\
\text { (warts, hypogammaglobulinemia, } \\
\text { infections, myelokathexis) szindróma }\end{array}$} & \multicolumn{2}{|l|}{ CXCR4 (AD GOF) } & & 1 \\
\hline & c. $1013 \mathrm{C}>\mathrm{G}$ & p.S338X & Nonsense & 1 \\
\hline \multicolumn{5}{|c|}{ Mucocutan candidiasisra való hajlam } \\
\hline \multirow[t]{3}{*}{ Krónikus mucocutan candidiasis (CMC) } & \multicolumn{2}{|l|}{ STATI (AD GOF) } & & 3 \\
\hline & c. $820 \mathrm{C}>\mathrm{T}$ & p.R274W & Missense & 2 \\
\hline & $c .1219 C>G$ & p. $L 407 W$ & Missense & 1 \\
\hline \multicolumn{5}{|c|}{ A TLR szignalizációs útvonal deficientiája bacterialis fogékonysággal } \\
\hline \multirow[t]{2}{*}{ IRAK4-deficientia } & $\operatorname{IRAK4}(\mathrm{AR})$ & & & 1 \\
\hline & IVS10-1G $>$ T $/$ IVS10 + 520A $>$ G & - & Splice site & 1 \\
\hline \multicolumn{5}{|l|}{ KOMPLEMENTDEFICIENTIÁK } \\
\hline \multirow[t]{3}{*}{ C2-deficientia } & $C 2(\mathrm{AR})$ & & & 2 \\
\hline & c.841_849del9bp, IVS6 + 1_19del19b & p (p.V281Pfs) & Nagydeletio & 2 \\
\hline & & Összesen & & 130 \\
\hline
\end{tabular}

Jelölések:

Félkövér mutáció: a Tanszék által diagnosztizált és publikált új mutáció.

Dôlt mutáció: a Tanszék által diagnosztizált, korábban még nem publikált új mutáció.

*: Prof. Dirk Roos (Sanquin Research and Karl Landsteiner Laboratory, Academic Medical Center, University of Amsterdam, Amsterdam, The

Netherlands) munkacsoportjával közös vizsgálat.

$\mathrm{AD}=$ autoszomális domináns; $\mathrm{AR}=$ autoszomális recesszív $; \mathrm{GOF}=$ funkciónyerő mutáció; $\mathrm{LOF}=$ funkcióvesztő mutáció; $\mathrm{RMRP}=\mathrm{RNA}$ component of mitochondrial RNA-processing endoribonuclease; XL = X-hez kötött; vt = vad típus

rek beállítását is. 2003-ban a Debreceni Egyetem Infektológiai és Gyermekimmunológiai Tanszékén jött létre immundeficientia molekuláris genetikai központ, amely országos igényt elégített ki, és a J Project révén kelet- és közép-európai centrummá vált. A hagyományos vizsgá- lómódszereken kívül a mutációanalízis és más molekuláris genetikai vizsgálatok elvégzése is biztosított volt. A ritka, öröklődő PID-ben szenvedő betegek és családtagjaik számára a praenatalis genetikai diagnosztika is hozzáférhető lett. A Tanszéken a 2003 és 2015 közötti idő- 
szakban genetikailag igazolt 130 magyarországi beteg genotípusát a 2. táblázat foglalja össze a legújabb PIDklasszifikációnak megfelelő felbontásban. A táblázat csak a betegek számadatait tartalmazza, a családszűrés során kiszűrt hordozók nem kerültek feltüntetésre.

Súlyos kombinált immundeficientiát (SCID) 6 esetben diagnosztizáltunk (ILRG-, illetve RAG2-mutáció), közel 20 esetben pedig a kombinált immundefektusok enyhébb formáit (CD40LG-, illetve DOCK8-mutáció) igazoltuk [30-33]. Az egyéb szindrómajelekkel társuló kombinált immundeficientiák között hiper-IgE-szindróma (11) [34], Wiskott-Aldrich-szindróma (WAS) (10) $[35,36]$, Nijmegen breakage szindróma (3) [37, 38], Di George-anomália (1), porc-haj hypoplasia (1) [39] és dyskeratosis congenita (1) $[40,41]$ fordult elö. Az antitestdeficientiák csoportjában X-kromoszómához kötött agammaglobulinaemia (18) [42] és AID-mutáció okozta hiper-IgM-szindróma (7) [31, 43] volt genetikailag igazolható. Az immundiszregulációs szindrómák között a legnagyobb számban X-kromoszómához kötött lymphoproliferativ szindrómát (XLP) (14) [44, 45] és APECED- (autoimmun polyendocrinopathia, candidiasis, ectodermalis dystrophia) szindrómát (13) [46] mutattunk ki, de előfordult autoimmun lymphoproliferativ szindróma (3) [47] és egy esetben IPEX- (immundiszreguláció, polyendocrinopathia, enteropathia, X-hez kötött) szindróma is. A phagocytadefektusok csoportjára X-kromoszómához kötött krónikus granulomás megbetegedés (CGD) (8) [48], congenitalis neutropenia (6) és Shwachman-Diamond-szindróma (SDS) (2) [49, 50] előfordulása volt jellemző. A természetes immunitás veleszületett zavarait krónikus mucocutan candidiasis (3), WHIM-szindróma $[51,52]$ és IRAK4-deficientia (1) $[53,54]$ formájában diagnosztizáltuk. Komplementdeficientia két esetben fordult elő. Praenatalis genetikai diagnosztikára 30 esetben került sor, ebből három esetben ikerterhességben. A praenatalis vizsgálatokra CD40LG-mutáció okozta kombinált immundeficientia (7), WAS (7), XLP (5), IL2RG-génmutáció okozta SCID (3), SDS (3), RAG2-mutáció okozta SCID (1), CYBB-génmutáció okozta CGD (1), ELANE-génmutáció okozta neutropenia (1), WHIM-szindróma (1) és IPEX-szindróma (1) miatt került sor $[55,56]$.

\section{Következtetés}

Megállapítható, hogy az NGS a veleszületett immunhiány-betegségek történetében is új fejezetet nyitott. A molekuláris genetikai vizsgálómódszerek lenyűgöző léptékű fejlődése nemcsak a PID-diagnosztikát forradalmasította, de lehetőséget teremtett új terápiás eljárások bevezetésére is. A terápiás kihívások egyike a mutánsgénőssejt transzfekcióval történő korrekciója, amelynek kezdeti eredményei több esetben biztatónak tûnnek, így remény van arra, hogy a génterápia hamarosan az első vonalbeli terápiás eljárások között szerepeljen.
Anyagi támogatás: A közlemény megírása, illetve a kapcsolódó kutatómunka anyagi támogatásban nem részesült.

A cikk végleges változatát a szerző elolvasta és jóváhagyta.

Érdekeltségek: A szerzőnek nincs érdekeltsége.

\section{Köszönetnyilvánítás}

Köszönetet mondok Bertrand Boissonnak (St. Giles Laboratory of Human Genetics of Infectious Diseases, The Rockefeller University, New York, USA) hasznos javaslataiért.

\section{Irodalom}

[1] Bousfiha A, Jeddane L, Picard C, et al. The 2017 IUIS phenotypic classification for primary immunodeficiencies. J Clin Immunol. 2018; 38: 129-143. [Epub 2017 Dec 11]

[2] Picard C, Bobby Gaspar H, Al-Herz W, et al. International Union of Immunological Societies: 2017 Primary Immunodeficiency Diseases Committee report on inborn errors of immunity. J Clin Immunol. 2018; 38: 96-128. [Epub 2017 Dec 11]

[3] Bruton OC. Agammaglobulinemia. Pediatrics 1952; 9: 722728.

[4] Maródi L. Inborn errors of T cell immunity underlying autoimmune diseases. Expert Rev Clin Immunol. 2017; 13: 97-99.

[5] Maródi L, Casanova JL. Novel primary immunodeficiencies relevant to internal medicine: novel phenotypes. J Intern Med. 2009; 266: 502-506.

[6] Maródi L, Notarangelo LD. Immunological and genetic bases of new primary immunodeficiencies. Nat Rev Immunol. 2007; 7 : 851-861.

[7] Bousfiha AA, Jeddane L, Ailal F, et al. Primary immunodeficiency diseases worldwide: more common than generally thought. J Clin Immunol. 2013; 33: 1-7.

[8] Kobrynski L, Powell RW, Bowen S. Prevalence and morbidity of primary immunodeficiency diseases, United States 2001-2007. J Clin Immunol. 2014; 34: 954-961.

[9] Picard C, Fischer A. Contribution of high-throughput DNA sequencing to the study of primary immunodeficiencies. Eur J Immunol. 2014; 44: 2854-2861.

[10] Babay LÉ, Horányi D, Rigó J Jr, et al. Next generation sequencing and its applications in non-invasive prenatal testing of aneuploidies. [Új generációs szekvenálás és használata az aneuploidák nem invazív praenatalis vizsgálatában.] Orv Hetil. 2015; 156 : 1041-1048. [Hungarian]

[11] Mihály Z, Győrffy B. Next generation sequencing technologies (NGST) development and applications. [Következő generációs szekvenálási technológiák kifejlődése és alkalmazásai.] Orv Hetil. 2011; 152: 55-62. [Hungarian]

[12] Sanger F, Nicklen S, Coulson AR. DNA sequencing with chainterminating inhibitors. Proc Natl Acad Sci USA 1977; 74: 54635467.

[13] Smith L, Sanders J, Kaiser R, et al. Fluorescence detection in automated DNA sequence analysis. Nature 1986; 321: 674679.

[14] Metzker ML, Raghavachari R, Richards S, et al. Termination of DNA synthesis by novel 3'-modified-deoxyribonucleoside 5'-riphosphates. Nucleic Acids Res. 1994; 22: 4259-4267.

[15] Ruiz-Martinez MC, Berka J, Belenkii A, et al. DNA sequencing by capillary electrophoresis with replaceable linear polyacrylamide and laser-induced fluorescence detection. Anal Chem. 1993; 65: 2851-2858. 
[16] Ronaghi M, Karamohamed S, Pettersson B, et al. Real-time DNA sequencing using detection of pyrophosphate release. Anal Biochem. 1996; 242: 84-89.

[17] Erdős M. Neonatal screening of severe combined immunodeficiencies. [A súlyos kombinált immundefektusok újszülöttkori szürővizsgálata.] Orv Hetil. 2018; 159: 948-956. [Hungarian]

[18] Itan Y, Casanova JL. Novel primary immunodeficiency candidate genes predicted by the human gene connectome. Front Immunol. $2015 ; 6: 142$

[19] Nijman IJ, van Montfrans JM, Hoogstraat M, et al. Targeted next-generation sequencing: a novel diagnostic tool for primary immunodeficiencies. J Allergy Clin Immunol. 2014; 133: 529534.

[20] Stoddard JL, Niemela JE, Fleisher TA, et al. Targeted NGS: a cost-effective approach to molecular diagnosis of PIDs. Front Immunol. 2014; 5: 531.

[21] Meyts I, Bosch B, Bolze A, et al. Exome and genome sequencing for inborn errors of immunity. J Allergy Clin Immunol. 2016; 138: 957-969.

[22] Belkadi A, Bolze A, Itan Y, et al. Whole-genome sequencing is more powerful than whole-exome sequencing for detecting exome variants. Proc Natl Acad Sci USA 2015; 112: 5473-5478.

[23] Starokadomskyy P, Gemelli T, Rios JJ, et al. DNA polymerase- $\alpha$ regulates the activation of type I interferons through cytosolic RNA:DNA synthesis. Nat Immunol. 2016; 17: 495-504.

[24] Conley ME, Casanova JL. Discovery of single-gene imborn errors of immunity by next generation sequencing. Curr Opin Immunol. 2014; 30: 17-23.

[25] Albert MH, Notarangelo LD, Ochs HD. Clinical spectrum, pathophysiology and treatment of the Wiskott-Aldrich syndrome. Curr Opin Hematol. 2011; 18: 42-48.

[26] Devriendt K, Kim AS, Mathijs G, et al. Constitutively activating mutation in WASP causes X-linked severe congenital neutropenia. Nat Genet. 2001; 27: 313-317.

[27] Boisson B, Quartier P, Casanova JL. Immunological loss-offunction due to genetic gain-of-function in humans: autosomal dominance of the third kind. Curr Opin Immunol. 2015; 32: 90-105.

[28] Erdôs M, Maródi L. Autoinflammatory syndromes - recurrent fever syndromes. [Autoinflammációs szindrómák - visszatéró lázszindrómák.] Focus Medicinae 2010; 12: 3-16. [Hungarian]

[29] Erdős M, Maródi L. Fever and fever syndromes. [Láz és lázszindrómák.] Gyermekorv Továbbk. 2010; 9: 9-11. [Hungarian]

[30] Erdős M, Alapi K, Maródi L. Retrospective diagnosis of X-linked hyper-IgM syndrome in a family with multiple deaths of affected males. Haematologica. 2007; 92: 281-282.

[31] Erdős M, Lakos G, Dérfalvi B, et al. Molecular genetic analysis of Hungarian patients with the hyper-immunoglobulin $M$ syndrome. Mol Immunol. 2008; 45: 278-282.

[32] Kellermayer R, Hsu AP, Stankovics J, et al. A novel IL2RG mutation associated with maternal $\mathrm{T}$ lymphocyte engraftment in a patient with severe combined immunodeficiency. J Hum Genet. 2006; 51: 495-497.

[33] Tóth B, Pistár Z, Csorba G, et al. Novel dedicator of cytokinesis 8 mutations identified by multiplex ligation-dependent probe amplification. Eur J Haematol. 2013; 91: 369-375.

[34] Jiao H, Tóth B, Erdôs M, et al. Novel and recurrent STAT3 mutations in hyper-IgE syndrome patients from different ethnic groups. Mol Immunol. 2008; 46: 202-206.

[35] Alapi K, Erdős M, Nagy A, et al. Mutation of Wiskott-Aldrich syndrome gene in a congenital thrombocytopenic infant. [Wiskott-Aldrich-szindróma génjének mutációja congenitalis thrombocytopeniás csecsemőben.] Gyermekgyógyászat 2005; 56: 135-139. [Hungarian]

[36] Gulácsy V, Freiberger T, Shcherbina A, et al. Genetic characteristics of eighty-seven patients with the Wiskott-Aldrich syndrome. Mol Immunol. 2011; 48: 788-792.
[37] Erdôs M, Tóth B, Veres I, et al. Nijmegen Breakage syndrome complicated with primary cutaneous tuberculosis. Pediatr Infect Dis J. 2011; 30: 359-360.

[38] Erdős M, Tóth B, Juhász P, et al. Nijmegen breakage syndrome. [Nijmegen-Breakage-szindróma.] Orv Hetil. 2010; 151: 665673. [Hungarian]

[39] Erdős M, Tóth B, Almássy Z, et al. Cartilage-hair hypoplasia. [Porc-haj hypoplasia.] Orv Hetil. 2008; 149: 209-217. [Hungarian]

[40] Reiger Z, Varga G, Tóth B, et al. Molecular diagnosis and therapeutic measures in patients with dyskeratosis congenita. [Dyskeratosis congenita: molekuláris diagnosztika és terápiás lehetőségek.] Orv Hetil. 2010; 151: 285-292. [Hungarian]

[41] Reiger Z, Varga G, Tóth B, et al. Dyskeratosis congenita diagnosed in adulthood. [Felnőttkorban diagnosztizált dyskeratosis congenita.] Gyermekgyógyászat 2010; 61: 66-70. [Hungarian]

[42] Tóth B, Volokha A, Mihas A, et al. Genetic and demographic features of X-linked agammaglobulinemia in Eastern and Central Europe: a cohort study. Mol Immunol. 2009; 46: 2140-2146.

[43] Erdős M, Maródi L. Autosomal recessive hyper-IgM syndrome. [Autoszomális recesszív hyper-IgM-szindróma.] Gyermekgyógyászat 2003; 54: 117-125. [Hungarian]

[44] Erdős M, Uzvölgyi É, Nemes Z, et al. Characterization of a disease-causing mutation of SH2D1A in a family with X-linked lym phoproliferative disease. Hum Mutat. 2005; 25: 506.

[45] Tóth B, Soltész B, Gyimesi E, et al. Severe XLP phenotype caused by a novel intronic mutation in the SH2DlA gene. J Clin Immunol. $2015 ; 35: 26-31$.

[46] Tóth B, Wolff AS, Halász Z, et al. Novel sequence variation of AIRE and detection of interferon- $\omega$ antibodies in early infancy. Clin Endocrinol. 2010; 72: 641-647.

[47] Erdős M, Maródi L. The clinics and molecular genetics of autoimmune lymphoproliferative syndrome. [Az autoimmun lymphoproliferativ szindróma klinikuma és molekuláris genetikája.] Gyermekgyógy Továbbk Szle. 2003; 8: 4-9. [Hungarian]

[48] Székely A, Péter M, Erdős M, et al. Hepatic abscess as the single manifestation of $\mathrm{X}$-linked chronic granulomatous disease. Pediatr Blood Cancer 2012; 58: 828-829.

[49] Erdős M, Alapi K, Balogh I, et al. Severe Shwachman-Diamond syndrome phenotype caused by missense mutation in the SBDS gene. Exp Hematol. 2006; 34: 1517-1521.

[50] Erdős M, Maródi L. Shwachman-Diamond syndrome: clinical manifestations and molecular genetics. [Shwachman-Diamondszindróma: Klinikai manifesztációk és molekuláris genetikai vizsgálatok.] Orv Hetil. 2007; 148: 513-519. [Hungarian]

[51] Alapi K, Erdős M, Kovács G, et al. Recurrent CXCR4 sequence variation in a girl with incomplete WHIM syndrome. Eur J Haematol. 2007; 78: 86-88.

[52] Erdős M, Maródi L. WHIM syndrome. [WHIM-szindróma.] Orv Hetil. 2007; 148: 1173-1179. [Hungarian]

[53] Erdős M, Maródi L. Selective anti-polysaccharide antibody deficiency syndrome and IRAK-4 deficiency in invasive pneumococcal infection. [Szelektív antipoliszacharidantitest-hiány szindróma és IRAK-4-deficientia invazív pneumococcus fertőzésben.] Gyermekgyógyászat 2005; 56: 115-121. [Hungarian]

[54] Ku CL, Picard C, Erdős M, et al. IRAK-4 and NEMO mutations in otherwise healthy children with recurrent invasive pneumococcal disease. J Med Genet. 2007; 44: 16-23.

[55] Alapi K, Erdős M, Török O, et al. Prenatal diagnosis of the WAS $\mathrm{R} 86 \mathrm{H}$ sequence variation in heterozygous twins. Clin Chem. 2006; 52: 901-903.

[56] Török O, Tóth B, Erdős M, et al. Molecular diagnostic challenges and complex management of consecutive twin pregnancies in a family with CD40 ligand deficiency. Scand J Immunol. 2012; 75: 227-230.

(Erdős Melinda dr., The Rockefeller University, 1230 York Avenue, Box 163, New York, NY 10065, USA e-mail: merdos@rockefeller.edu) 